\title{
Neurotrophins and the Neuroendocrine Brain: Different Neurotrophins Sustain Anatomically and Functionally Segregated Subsets of Hypothalamic Dopaminergic Neurons
}

\author{
Karin Berg-von der Emde, ${ }^{1}$ W. Les Dees, ${ }^{2}$ Jill K. Hiney, ${ }^{2}$ Diane F. Hill, ${ }^{1}$ Gregory A. Dissen, ${ }^{1}$ Maria E. Costa, ${ }^{1}$ \\ Melissa Moholt-Siebert, ${ }^{1, a}$ and Sergio R. Ojeda' \\ ${ }^{1}$ Division of Neuroscience, Oregon Regional Primate Research Center-Oregon Health Sciences University, \\ Beaverton, Oregon 97006 and ${ }^{2}$ Department of Veterinary Anatomy and Public Health, Texas A\&M University, \\ College Station, Texas 77843
}

Hypothalamic neurons control a variety of important hormonal and behavloral functions. Little is known, however, about the neurotrophic factors that these neurons may require for survival and/or maintenance of their differentiated functions. We conducted experiments to examine this issue, utilizing a combination of immunohistochemical, in situ hybridization and cell culture approaches. We found that the low affinity receptor for nerve growth factor (p75 NGFR) is present in small subsets of hypothalamic peptidergic neurons identified as such by their content of galanin, luteinizing hormone-releasing hormone (LHRH) and vasointestinal peptide (VIP). More prominently, however, examination of hypothalamic dopaminergic (DA) neurons for the presence of p75 NGFR-like immunoreactivity revealed that the receptor was present on tyrosine hydroxylase (TH)-positive neurons of the zona incerta and periventricular region, but not on neuroendocrine DA neurons of the tuberoinfundibular region. In situ hybridization experiments using a p75 NGFR cRNA confirmed this distribution. Regardless of the presence or absence of p75 NGFR, neither DA group expresses trkA mRNA, indicating that these two major hypothalamic subsets of DA neurons are NGFinsensitive. A substantial fraction of TH mRNA-positive cells in the zona incerta expresses trkB mRNA, which encodes the receptor for brain derived neurotrophic factor (BDNF); in turn BDNF supports the in vitro survival of hypothalamic TH neurons bearing p75-NGFR, suggesting that BDNF is trophic for DA neurons of the zona incerta. In contrast, tuberoinfundibular DA neurons do not express trkB mRNA, but some have trkC mRNA, which encodes the receptor for neurotrophin-3 (NT-3). The in vitro survival of TH neurons devoid of p75-NGFR is supported by NT-3, implying that NT-3 may be trophic for a subset of tuberoinfundibular DA neurons. These results suggest that, in spite of expressing an identical neurotransmitter phenotype, ana-

\footnotetext{
Received Nov. 29, 1994; revised Feb. 1, 1995; accepted Feb. 3, 1995.

This work was supported by Grants HD-25123, HD-07138, HD-18185, AA 00104 , and AA-07216 from the National Institutes of Health. This is publication 1949 of the Oregon Regional Primate Research Center.

Correspondence should he addressed to Seroin R. Ojeda, D.V.M., Division of Neuroscience, Oregon Regional Primate Research Center, 505 N.W. 185th Avenue, Beaverton, OR 97006.

aPresent address: Department of Cell Biology and Anatomy (L215), Oregon Health Sciences University, Portland, OR 97201

Copyright (C) 1995 Society for Neuroscience $0270-6474 / 95 / 154223-15 \$ 05.00 / 0$
}

tomically and functionally segregated DA neurons of the neuroendocrine brain are sustained by different neurotrophic factors.

[Key words: neurotrophins, neurotrophin receptors, hypothalamic neurons, dopaminergic neurons, neuronal survival, neuroendocrine brain]

It is well established that the CNS produces a variety of soluble polypeptides which support the growth, cellular differentiation, and survival of neurons. Prominent among these proteins is the neurotrophic family of growth factors which include NGF, brainderived neurotrophic factor (BDNF), neurotrophin-3 (NT-3), and neurotrophin 4/5 (Levi-Montalcini, 1987; Leibrock et al., 1989; Maisonpierre et al., 1990b; Ernfors et al., 1990; Hohn et al., 1990; Rosenthal et al., 1990; Berkemeier et al., 1991; Hallböök et al., 1991; Ip et al., 1992). Different members of the neurotrophin family have been shown to promote the survival of specific neuronal subpopulations in brain. Thus, while the trophic effects of NGF are limited to cholinergic neurons of the basal forebrain (Hefti, 1986), BDNF supports the survival and differentiation of both cholinergic neurons of the basal forebrain (Alderson et al., 1990; Knuisel et al., 1991; Lamballe et al., 1994) and dopaminergic (DA) neurons of the substantia nigra/ventral mesencephalon (Hyman et al., 1991; Knüsel et al., 1991). In contrast to BDNF and NGF, NT-3 does not affect the survival and/or differentiation of cholinergic neurons of the basal forebrain (Knüsel et al., 1991). NT-3 does, however, promote the survival of mesencephalic DA neurons (Hyman et al., 1994) and exert trophic effects on developing hippocampal cells (Collazo et al., 1992).

All neurotrophins bind with low affinity to a membrane spanning receptor molecule known as the low-affinity NGF receptor (p75-NGFR) (reviewed in Meakin and Shooter, 1992). Although p75-NGFR may contribute to the initiation of NGF biological actions (Hempstead et al., 1991, reviewed in Bothwell, 1991, and Meakin and Shooter, 1992) it is now well established that the trophic effects of all neurotrophins, including NGF (Jing et al., 1992), require binding to recognition molecules of the $t r k$ tyrosine protein kinase family of receptors (Barbacid et al., 1991; Meakin and Shooter, 1992). This family includes trkA, which preferentially binds NGF (Kaplan et al., 1991; Klein et al., 1991); trkB, which recognizes BDNF and NT-4/5 (Squinto et al., 1991; Soppet et al., 1991; Klein et al., 1992; Ip et al., 1993); and $t r k \mathrm{C}$, the receptor preferred by NT-3 (Lamballe et al., 1991; Tsoulfas et al., 1993). 

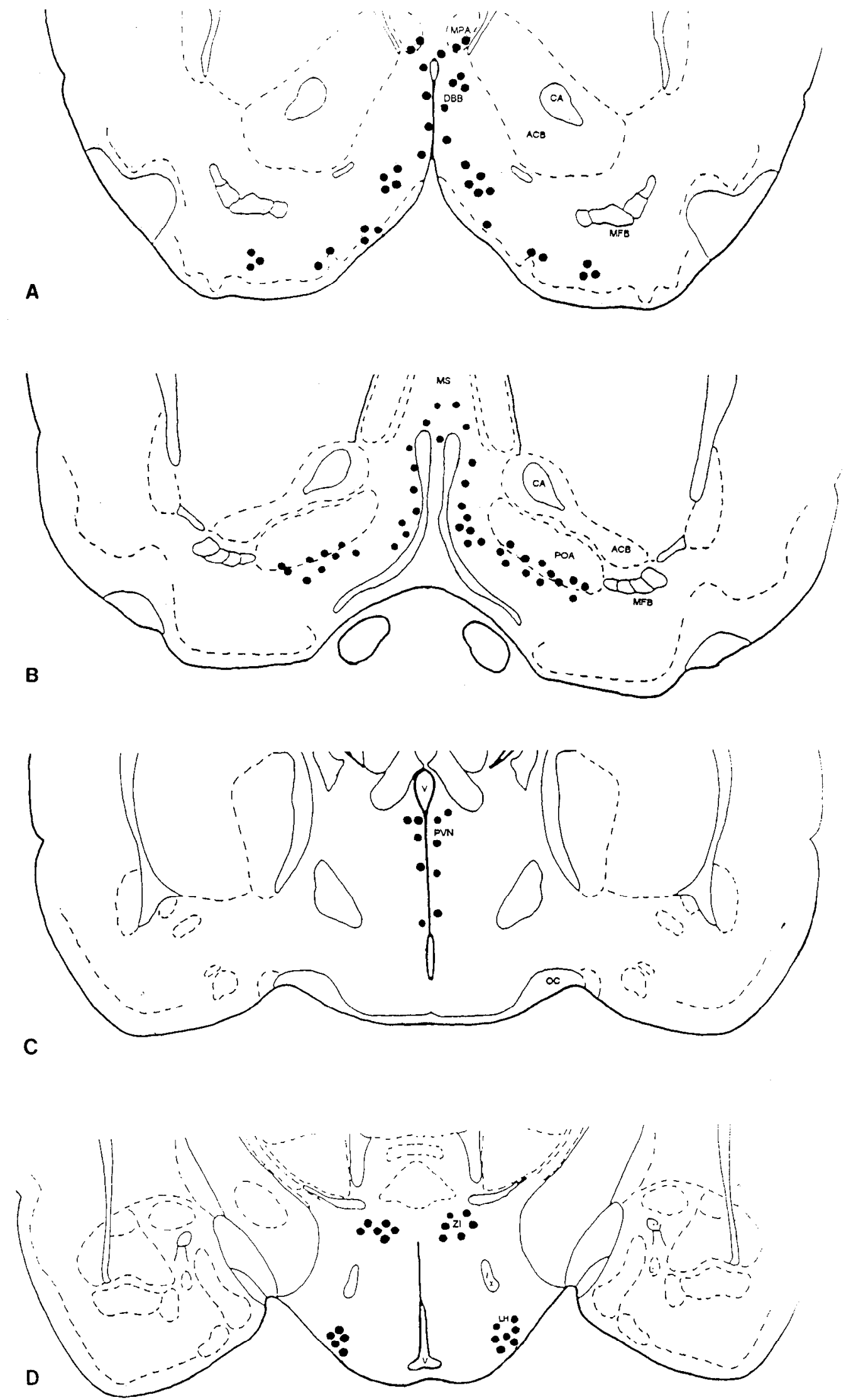

Figure 1. Drawing depicting the rostrocaudal $(A-D)$ distribution of p75-NGFR-positive neurons localized by immunohistochemistry in the immature rat forebrain and hypothalamus. The number of dots represents the relative density of positive cells within the respective regions. $M P A, M e d i a l$ preoptic area; $P O A$, preoptic area; $D B B$, diagonal band of Broca; $P V N$, paraventricular nucleus; $L H$, lateral hypothalamus; $Z I$, zona incerta; $C A$, commissura anterior; $O C$, optic chiasm; $F X$, fornix; $V$, third ventricle; $A C B$, nucleus accumbens; $M F B$, median forebrain bundle; $M S$, medial septum. 

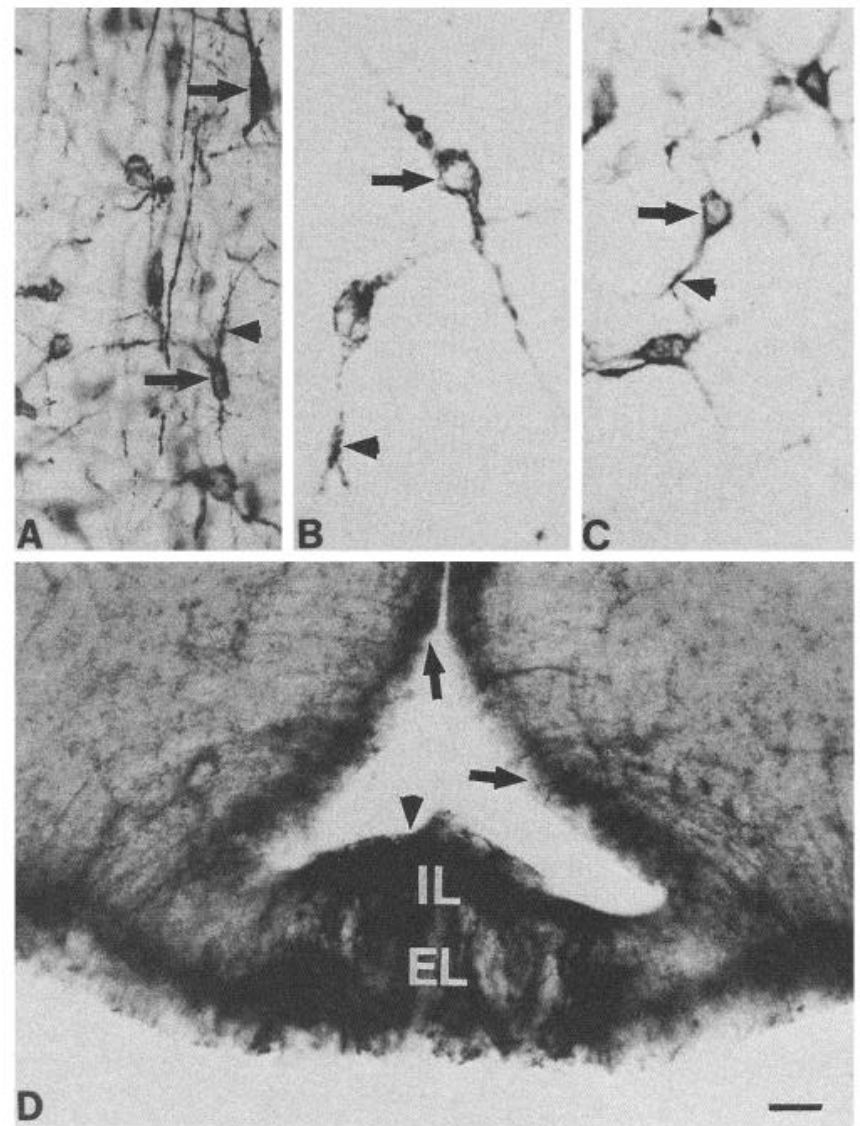

Figure 2. Localization of the p75-NGFR immunoreactive material in the immature rat forebrain and hypothalamus. $A-C$, Note the immunoreactivity on the soma (arrows) and processes (arrowheads) of neurons in the diagonal band of Broca $(A)$, zona incerta $(B)$, and lateral hypothalamic area $(C) . D$, Depicts the intense immunoreactivity on the ependymal (tanycyte) cells lining the wall (arrows) and the floor (arrowheads) of the third ventricle, and on their processes within the internal and external layers of the median eminence. $I L$, Internal layer; $E L$, external layer. Scale bars: $A, 15 \mu \mathrm{m} ; B$ and $C, 7 \mu \mathrm{m} ; D, 30 \mu \mathrm{m}$.

To date, a great deal of attention has been devoted to the presence of neurotrophins and their receptors in different brain areas and to the trophic effects that neurotrophins may exert on cholinergic neurons of the basal forebrain and mesencephalic DA neurons. Little is known, however, about the neuronal populations that may be responsive to neurotrophins in the hypothalamus - a region of the CNS critically important not only for the control of the endocrine system, but also for the manifestation of a variety of behavioral functions. Distribution studies have shown that while the developing postnatal hypothalamus expresses BDNF mRNA (Maisonpierre et al., 1990a; Friedman et al., 1991), it contains only very low levels of NGF mRNA (Korsching et al., 1985; Gonzalez et al., 1990) and no NT-3 mRNA (Ernfors et al., 1990). Within the hypothalamus, BDNF expression is more prominent in the ventromedial nucleus of the medial basal hypothalamus and the preoptic area in the rostral hypothalamus (Friedman et al., 1991).

Neurotrophic receptors are also found in the neuroendocrine brain. For instance, the hypothalamus expresses p75-NGFR mRNA (Ojeda et al., 1990) and displays active p75-NGFR protein, as assessed by cross-linking assays (Ojeda et al., 1990). At the cellular level, the most predominant sites of expression of p75-NGFR have been localized immunohistochemically to the suprachiasmatic nucleus and tanycytes of the third ventricle (Yan and Johnson, 1988; Koh et al., 1989). Less information exists concerning the hypothalamic expression of trk genes. Although a general inspection revealed no trkA mRNA-expressing cells in this region (Holtzman et al., 1992), trkB mRNA was detected throughout the medial hypothalamic region (Valenzuela et al., 1993) and in the median eminence (Klein et al., 1990). Recent in situ hybridization studies revealed the presence of trkC mRNA in the dorsal and ventromedial nuclei of the medial hypothalamus and the median eminence (Lamballe et al., 1994).

The present study was undertaken to identify some of the neuronal populations responsive to neurotrophins in the developing hypothalamus. To this end, we first identified the neurotransmitter phenotypes of those hypothalamic neurons displaying immunoreactive p75-NGFR, then defined the type of trk receptor expressed by the most prominent subset of p75-NGFRcontaining neurons and, lastly, determined the ability of different neurotrophins to promote the survival of these neurons in culture. The results suggest that the two major groups of hypothalamic dopaminergic neurons-those of the zona incerta and those of the tuberoinfundibular region-differ in their sensitivity to neurotrophins. While both the p75-NGFR and trkB genes are expressed in DA neurons of the zona incerta, no detectable levels of either receptor mRNA were seen in tuberoinfundibular DA neurons; however, some of these neurons contain trkC mRNA. As cultured hypothalamic DA neurons expressing p75NGFR were found to require BDNF for survival, whereas DA neurons devoid of p75-NGFR are sustained by NT-3, the results suggest that BDNF is mostly trophic for DA neurons of the zona incerta whereas NT-3 mainly supports the survival of tuberoinfundibular DA neurons.

A partial report of these findings has appeared (Dees et al., 1993).

\section{Materials and Methods}

\section{Animals}

Localization of neurotrophin receptors in hypothalamic neurons by either immunohistochemistry or hybridization histochemistry was performed in immature 28-29 d old female Sprague-Dawley rats. Assessment of neuronal survival in response to neurotrophins was carried out in primary neuronal cultures prepared from $18 \mathrm{~d}$ old rat fetuses.

\section{Antibodies}

p75-NGFR was identified with monoclonal antibody IgG 192 (kindly provided by Dr. Eugene Johnson, Washington University School of Medicine, St. Louis, MO). This antibody, developed by Chandler et al. (1984), has been extensively used for the immunohistochemical detection of p75-NGFR by several investigators (Taniuchi et al., 1988; Yan and Johnson, 1988), including ourselves (Dissen et al., 1991). Neurons were identified with an antiserum to neuron specific enolase (NSE, Polysciences Inc., Warrington, PA), the $\gamma \gamma$-isoenzyme of enolase (2-phospho-D-glycerate hydrolase) which is expressed in neurons and neuroendocrine cells (Marangos and Schmechel, 1987).

Double-label immunohistochemistry was performed using antiNGFR and the following polyclonal antisera: anti-choline acetyltransferase (CAT, kindly provided by Dr. Louis B. Hersh, Southwestern Medical Center, Dallas, TX), anti-galanin (GAL, kindly provided by Dr. Jim Koenig, Immunobiology Research Institute, Allendale, NJ), anti-interleukin I $\alpha$ (IL- $1 \alpha$, Genzyme, Boston, MA), anti-tyrosine hydroxylase (TH, Eugene Tech, Allendale, NJ), and anti-neuropeptide Y (NPY, Dr. J. K. McDonald, Emory University School of Medicine, Atlanta, GA). Luteinizing hormone releasing hormone (LHRH)-containing neurons were identified using monoclonal antibody $4 \mathrm{H} 3$ (kindly provided by $\mathrm{Dr}$. Henryk Urbanski, Oregon Regional Primate Research Center, Beaverton, OR). 

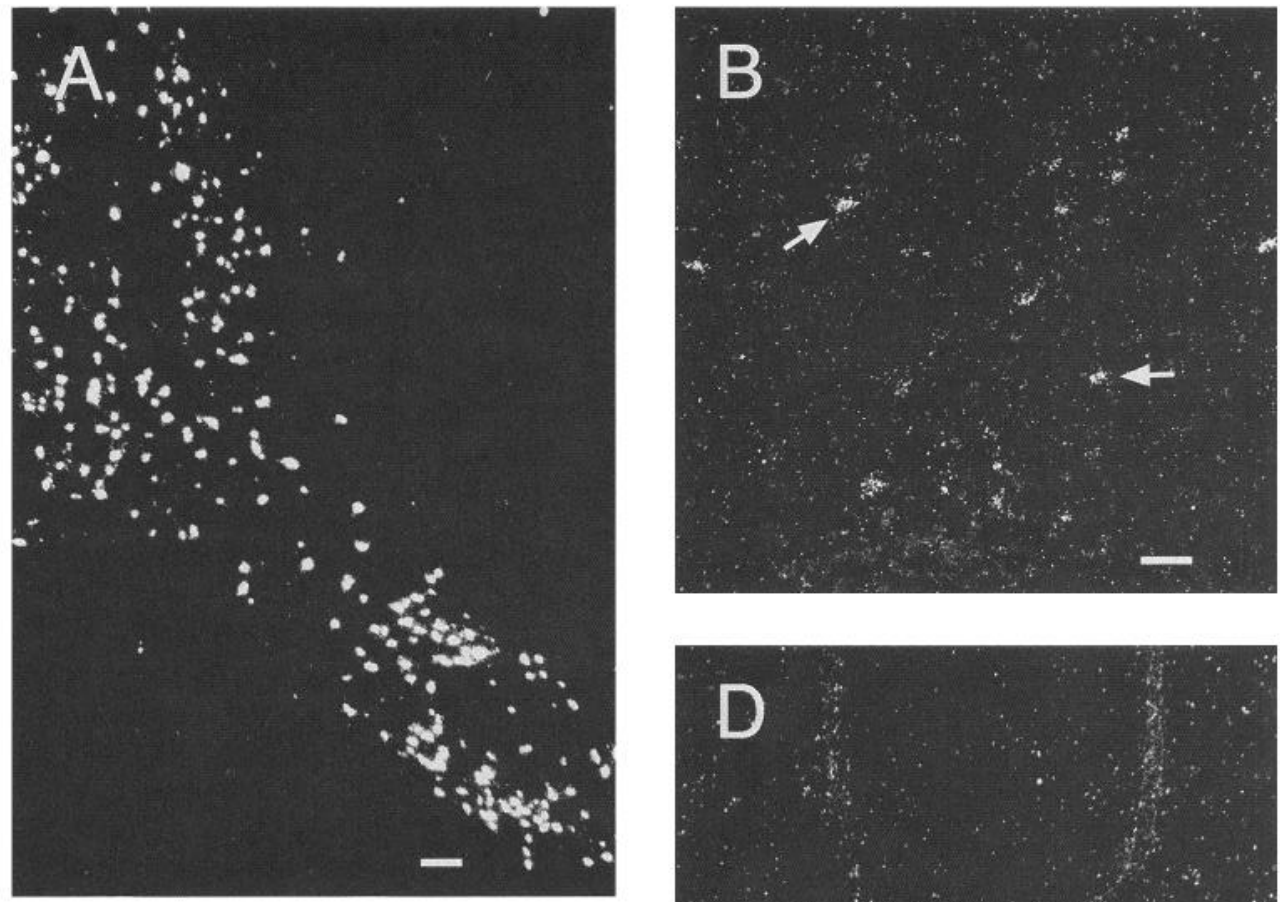

Figure 3. Localization of p75-NGFR mRNA in the forebrain and hypothalamus of immature rats by hybridization histochemistry. A, The diagonal band of Broca; $B$, zona incerta; $C$, lateroventral hypothalamus; $D$, absence of detectable p75-NGFR mRNA in the arcuate nucleus-median eminence region of the hypothalamus. Scale bars: $A, 40$ $\mu \mathrm{m} ; B$ and $D, 20 \mu \mathrm{m} ; C, 10 \mu \mathrm{m}$.
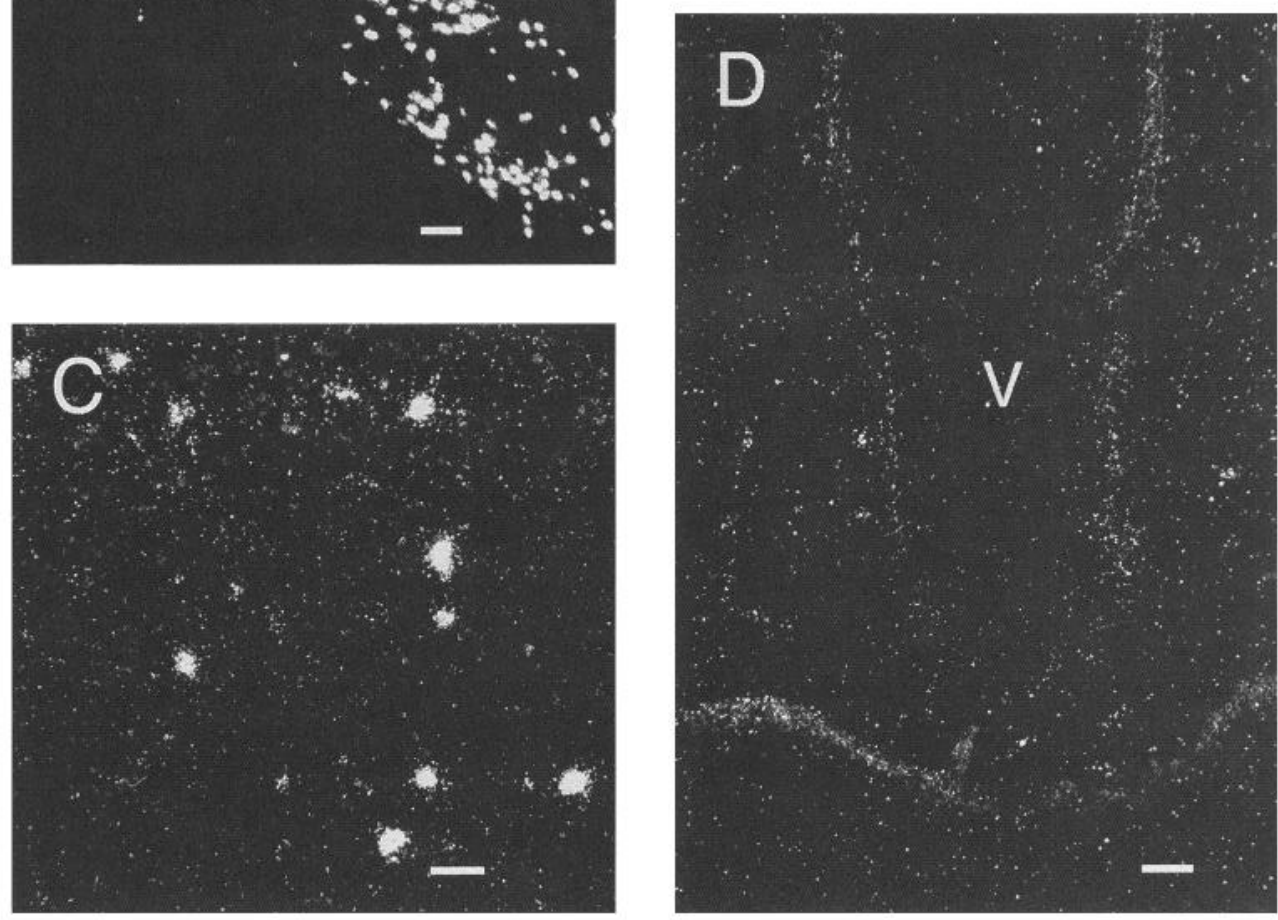

\section{Immunohistochemistry}

NGFR. Animals were transcardially perfused with isotonic saline and then perfusion-fixed with Zamboni's solution. The brains were removed and postfixed in the same fixative for $24 \mathrm{hr}$, then kept in $0.05 \mathrm{M}$ Tris buffered saline (TBS) pH 7.6 at $4^{\circ} \mathrm{C}$ until sectioning.

Immunocytochemical staining was performed on $40 \mu \mathrm{m}$ Vibratome sections which were floated in $0.05 \mathrm{M}$ TBS, pH 7.6. After three $10 \mathrm{~min}$ washes in TBS, the sections were floated for $2 \mathrm{hr}$ in TBS containing $1 \% \mathrm{H}_{2} \mathrm{O}_{2}$ to inhibit endogenous peroxidases. Sections were rinsed in TBS, and then washed twice for 10 min each in TBS A (TBS plus $0.5 \%$ bovine serum albumin and $0.2 \%$ Triton $\mathrm{X}-100$ ) and twice for $10 \mathrm{~min}$ each with TBS B (TBS plus $1.5 \%$ normal goat serum). Brain sections from the diagonal band of Broca, rostrally, to the arcuate nucleus/median eminence region, caudally, were incubated with a $7.5 \mu \mathrm{g} / \mathrm{ml} \mathrm{di}$ lution of the anti-p75-NGFR serum for $24 \mathrm{hr}$ at $4^{\circ} \mathrm{C}$. Tissues were rinsed as above in TBS A and TBS B, then incubated for $1 \mathrm{hr}$ at room temperature with preabsorbed biotinylated horse anti-mouse IgG (Vector Laboratories, Burlingame, CA) at a dilution of 1:250. After washes in the two buffers, the sections were incubated in the avidin-biotin complex $(\mathrm{ABC})$ for $75 \mathrm{~min}$ at room temperature. The sections were rinsed and exposed to TBS containing $0.02 \% 3,3^{\prime}$-diaminobenzidine $\mathrm{HCl}$ (DAB) with $0.003 \% \mathrm{H}_{2} \mathrm{O}_{2}$ and $2.5 \%$ nickel for $10 \mathrm{~min}$, generating a black reaction product due to the nickel intensification of the dark brown, DAB stain. The reaction was stopped by washing in TBS; then the sections were mounted on gelatin-coated slides. Finally, they were dehydrated in graded alcohols, cleared in Histoclear (VWR Scientific, Philadelphia, PA), coverslipped, and viewed with a Leitz microscope.

Double-label immunohistochemistry. These experiments were performed to determine the neuronal phenotypes expressing p75-NGFR. The tissues were first overlaid with either (1) anti-CAT (1:1000), (2) anti-GAL (1:250), (3) anti-IL-I $\alpha$ (1:400), (4) anti-NPY (1:500), (5) antiLHRH $(1: 1000)$, or (6) anti-TH $(1: 500)$. The localization of each of these substances was visualized using the procedure described above except that the second antibody was biotinylated goat anti-rabbit-IgG $(1: 250)$ and the tissues were exposed to $\mathrm{DAB} / \mathrm{H}_{2} \mathrm{O}_{2}$ only (without nickel) yielding a dark brown final reaction product. After the DAB stain, the tissues were washed in TBS, then the above described procedure for immunohistochemical localization of NGFR was followed except the $\mathrm{DAB} /$ nickel intensification staining procedure was replaced with the previously described benzidine dihydrochloride procedure (Lokos and Basbaum, 1986), which yields a punctate dark blue reaction product (Junier et al., 1991).

In the case of hypothalamic cultures, TH positive neurons were identified using the TH antiserum at a 1:1500 dilution and p75-NGFR using 

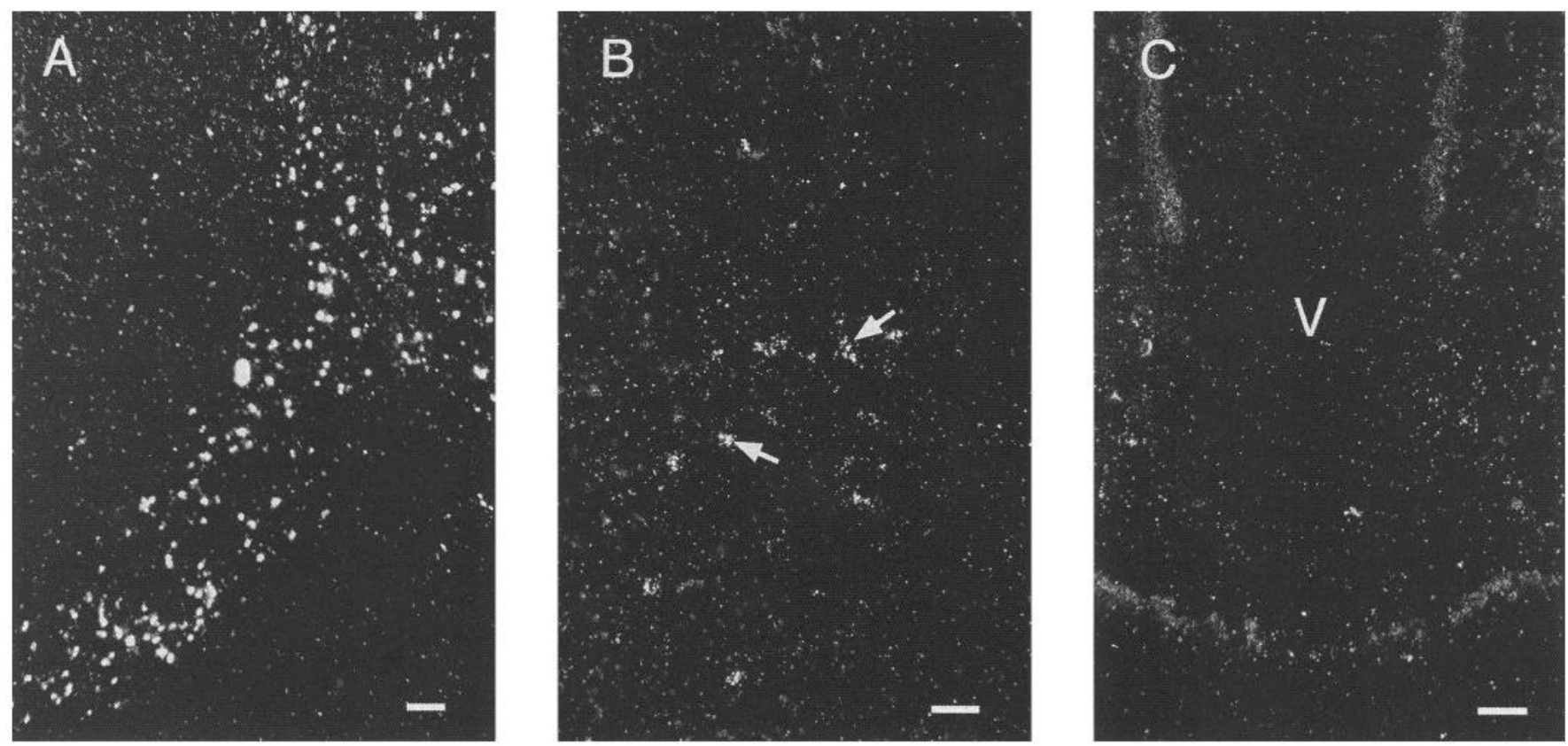

Figure 4. Localization of trkA mRNA in the forebrain and hypothalamus of immature rats by hybridization histochemistry. A, Diagonal band of Broca; $B$, lateroventral hypothalamus; $C$, absence of detectable trkA mRNA in the arcuate nucleus-median eminence region of the hypothalamus. Scale bars: $A, 40 \mu \mathrm{m} ; B$ and $C, 20 \mu \mathrm{m}$.

antibody IgG 192 at $2 \mu \mathrm{g} / \mathrm{ml}$. The NSE antiserum employed for the broad identification of neurons was used at a 1:500 dilution. The immunohistochemical reactions were developed as described above.

\section{Hybridization histochemistry}

The hybridization protocol used, which is based on that reported by Simmons et al. (1989), has been described elsewhere (Dissen et al., 1991; Junier et al., 1991). The brains were fixed by transcardiac perfusion with $4 \%$ paraformaldehyde in borate buffer $\mathrm{pH} 9.5$, postfixed at $4^{\circ} \mathrm{C}$ for $18 \mathrm{hr}$ in the same fixative containing $10 \%$ sucrose, blocked, and stored at $-85^{\circ} \mathrm{C}$ in air-tight containers before further processing. Twenty micrometer sections were prepared with a sliding microtome, mounted on Superfrost Plus (Fisher Scientific, Kent, WA) precleaned slides, dried overnight, and stored at $-85^{\circ} \mathrm{C}$ before hybridization. Following treatment with proteinase $\mathrm{K}$ and acetic anhydride (Simmons et al., 1989), the sections were overlaid with $70 \mu \mathrm{l}$ of hybridization solution (50\% formamide, $0.2 \mathrm{M} \mathrm{NaCl}, 10 \mathrm{~mm}$ Tris, $\mathrm{pH} 8.0,10 \mathrm{~mm}$ EDTA, $2 \times$ Denhardt's solution) containing $1 \times 10^{7} \mathrm{cpm} / \mathrm{ml}$ labeled probe $(\mathrm{p} 75$ NGFR, trkA or TH cRNA, see below). Hybridization was for $18-20 \mathrm{hr}$ at $55-60^{\circ} \mathrm{C}$; thereafter, the slides were washed four times in $4 \times$ sodium chloride-sodium citrate (SSC) prior to RNase A digestion $(20 \mu \mathrm{g} / \mathrm{ml}$ for $30 \mathrm{~min}$ at $37^{\circ} \mathrm{C}$ ), rinsed at room temperature in decreasing concentrations of $\operatorname{SSC}(2,1$, and $0.5 \times)$ containing $1 \mathrm{~mm}$ dithiothreitol (DTT) to a final stringency of $0.1 \times \mathrm{SSC}$ at $65^{\circ} \mathrm{C}$ for $30 \mathrm{~min}$. After dehydration in graded alcohols also containing $1 \mathrm{~mm}$ DTT and $0.1 \times$ SSC, the slides were exposed to Hyperfilm x-ray film for $3 \mathrm{~d}$, defatted, and dipped in NTB-2 emulsion. The reaction was developed 3 weeks later, the sections were counterstained with $0.1 \%$ thioneine and analyzed under both bright- and dark-field illumination.

For experiments involving double label in situ hybridization, a combination of the above protocol and a modification of the nonisotopic in situ hybridization protocol described by Springer et al. (1990) was used. Digoxygenin UTP-labeled $t r k \mathrm{~B}$ and $t r k \mathrm{C}$ cRNAs were prepared by in vitro transcription using $1 \mu \mathrm{l}$ of a $2 \mathrm{mM}$ digoxigenin-UTP solution; $500 \mathrm{ng}$ of cDNA template (see below); $2.5 \mathrm{~mm}$ of each ATP, CTP, and GTP; and 15-20 U of either SP6 (trkB) or T3 (trkC) RNA polymerase. Following $1 \mathrm{hr}$ of incubation at either $40^{\circ} \mathrm{C}(\operatorname{trkB})$ or $37^{\circ} \mathrm{C}$ $(\operatorname{trkC})$, the reaction mixtures were treated with DNase, stabilized with DTT and salt, and the volume was adjusted to $100 \mu \mathrm{l}$ with $20 \mathrm{~mm}$ DTT. The cRNA transcripts were then precipitated with ethanol, dried and resolubilized in $100 \mu \mathrm{l}$ diethyl pyrocarbonate (DEPC)-treated water. Five microliters of the mixture were then run on a formaldehyde- agarose gel to assess the integrity of the cRNAs and the yield of the reaction. For hybridization, 25-50 $\mu \mathrm{l}$ of either digoxygenin-labeled cRNA were added to $500 \mu \mathrm{l}$ of hybridization buffer containing $1 \times$ $10^{7} \mathrm{cpm} / \mathrm{ml}$ of ${ }^{35} \mathrm{~S}-\mathrm{UTP}$ TH cRNA. Following hybridization and posthybridization washes, which were carried out as described above, the slides were not dehydrated after the last 0.1 SSC wash, but instead were incubated overnight in $2 \times$ SSC containing $0.05 \%$ Triton X-100 and $2 \%$ normal goat serum at room temperature. The next day the slides were incubated with anti-digoxygenin-alkaline phosphatase conjugate $(1: 1000)$ for $5 \mathrm{hr}$ at room temperature. The slides were then rinsed and incubated overnight at room temperature in a chromogen solution containing $0.338 \mathrm{mg} / \mathrm{ml} \mathrm{4-nitroblue} \mathrm{tetrazolium} \mathrm{chloride}$ (NTB) and $0.175 \mathrm{mg} / \mathrm{ml} \mathrm{5-bromo-4-chloro-3-indoyl-phosphate} \mathrm{(BCIP)}$ and $3 \mathrm{mg} / \mathrm{ml}$ of levamisole. The staining reaction was then stopped by placing the slides in $10 \mathrm{~mm}$ Tris- $\mathrm{HCl}$ with $1 \mathrm{~mm}$ EDTA, $\mathrm{pH} 8$. After extensive washes in potassium phosphate-sodium chloride buffer $\mathrm{pH} 7.4$, the sections were quickly dehydrated in ethanol containing DTT and $2 \times$ SSC, dried under vacuum, examined for digoxygeninlabeled $t r k \mathrm{~B}$ or $\operatorname{trkC} \mathrm{cRNA}$ hybridization, and processed for autoradiography to detect ${ }^{35} \mathrm{~S}$-labeled $\mathrm{TH}$ mRNA hybrids. To avoid chemoautoradiographic signals, the slides were dipped in Ilford K5 emulsion (without defatting) instead of the NTB-2 emulsion used for regular isotopic hybridization. After 2 weeks of exposure the slides were developed, quickly dehydrated, dried under vacuum for $30 \mathrm{~min}$, and coverslipped for microscopic examination.

\section{Nucleic acid probes}

p75-NGFR mRNA was detected with a 271 nucleotide (nt) cRNA transcribed from a rat cDNA complementary to nt 430-700 in p75-NGFR mRNA (Buck et al., 1988) subcloned into the pGEM-3Z vector. Transcription of the antisense strand was performed using SP6 polymerase. trkA mRNA was detected with a trkA cRNA complementary to nt 273747 in trkA mRNA (Meakin et al., 1992). Transcription of the antisense strand from the cDNA template subcloned into pGEM-3Z was also directed by SP6 polymerase. TH mRNA was detected with a $280 \mathrm{nt}$ TH cRNA complementary to nt 1241-1521 in TH mRNA (Grima et al., 1985); the probe was transcribed with SP6 polymerase from a cDNA template subcloned into the pGEM-3Z vector. $t r k \mathrm{~B}$ mRNA was detected with a $241 \mathrm{nt}$ antisense RNA complementary to nt $2344-2585$ in the intracellular-encoding domain of $t r k \mathrm{~B}$ mRNA (Middlemas et al., 1991); the cDNA template was subcloned into the pGEM-3Z vector. $t r k \mathrm{C}$ was identified with a 409 nt cRNA probe complementary to nt 2266-2675 
Figure 5. Double-label immunohistochemistry illustrating specific neuronal phenotypes expressing p75NGFR. A, Arrows depict three CATpositive neurons (brown) in the diagonal band of Broca that also express p75-NGFR (punctate blue). Arrowheads depict other neurons that are CAT-negative, but NGFR-positive. $B$ Arrow depicts a GAL-positive neuron (brown) in the paraventricular nucleus of the hypothalamus that also expresses the NGFR (punctate blue). The arrowhead depicts a GAL-positive neuron that is NGFR-negative. $C$ demonstrates two immunopositive IL-I $\alpha$-immunopositive neurons in the lateral preoptic area that are NGFR-negative (arrows) and one neuron that is IL-I $\alpha$-negative but p75-NGFR-positive (arrowhead). $D$ and $E$ illustrate NPY-positive neurons in the cortex and arcuate nucleus of the hypothalamus, respectively. Note that only NPY neurons in the cortex express NGFR, as illustrated in $D$ by the punctate reaction on the soma. $F$ and $G$ demonstrate LHRH-positive neurons in the medial preoptic area. Note that one LHRH neuron is NGFRpositive $(F)$ as depicted by the punctate blue reaction, whereas the other LHRH neuron is NGFR-negative $(G)$. Scale bar: $A, 10 \mu \mathrm{m} ; B-E, 7 \mu \mathrm{m}$.
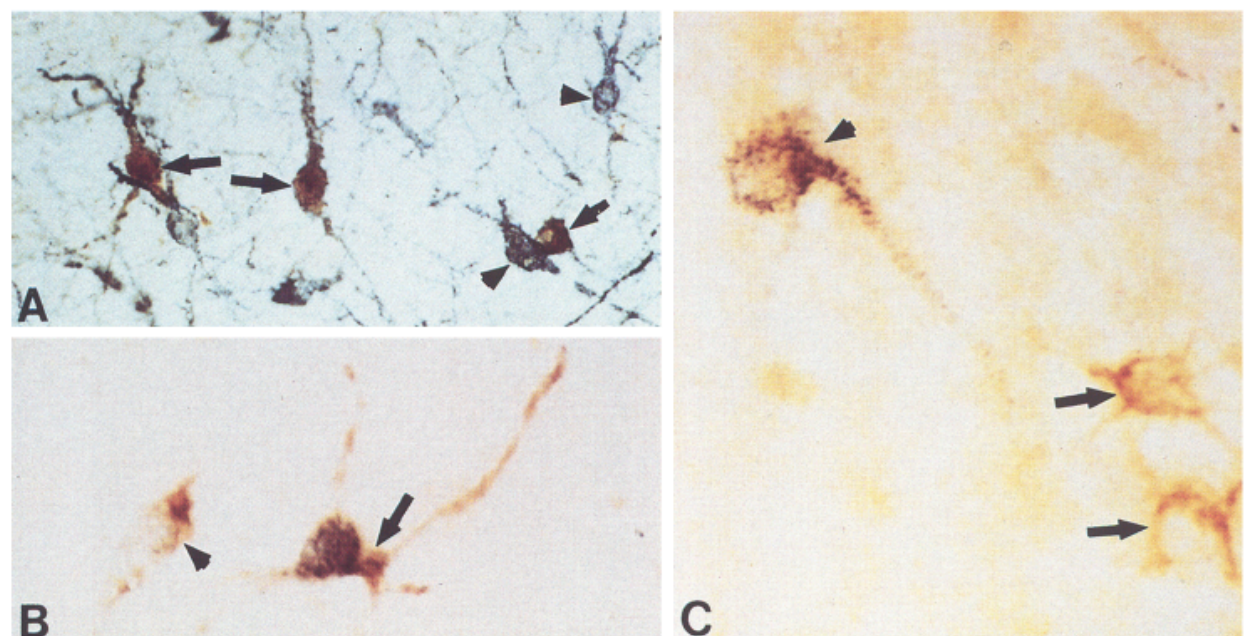

B
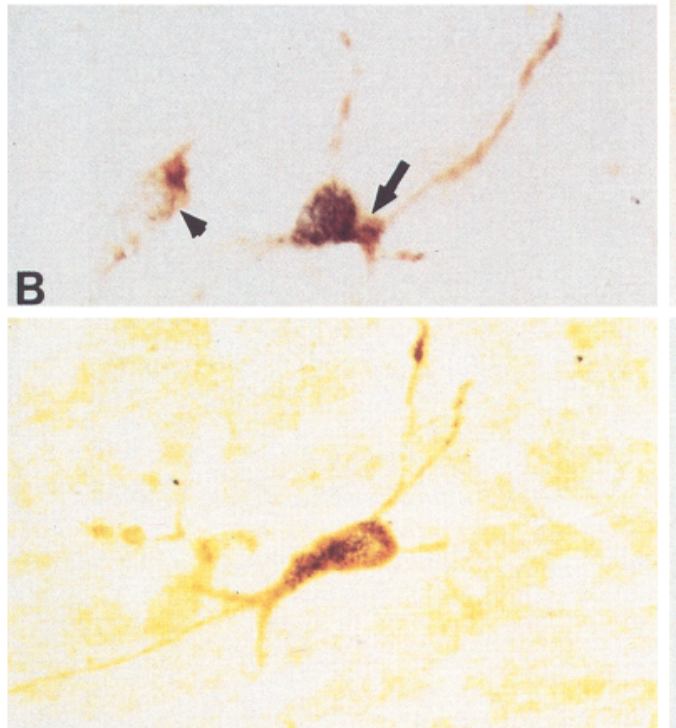

D

E
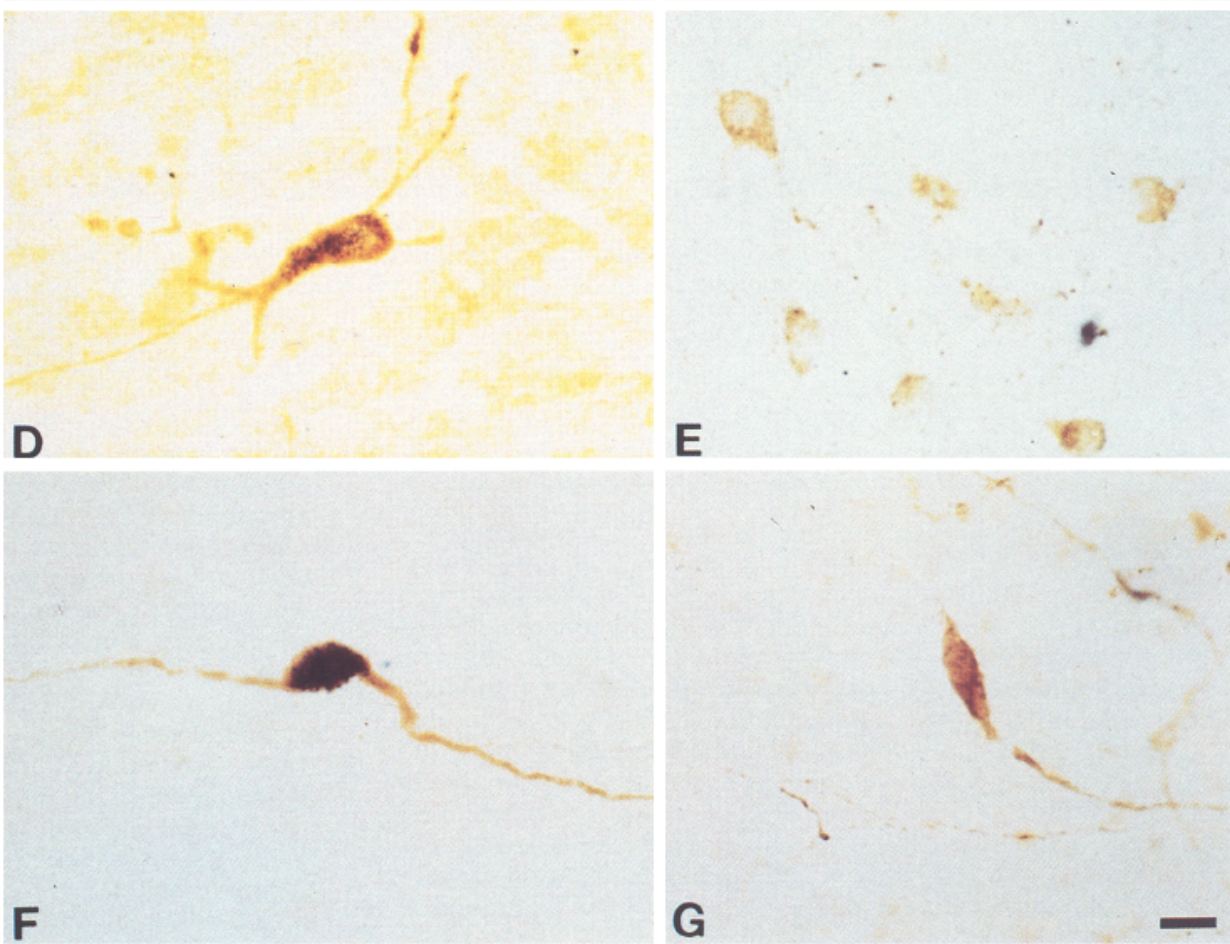

G

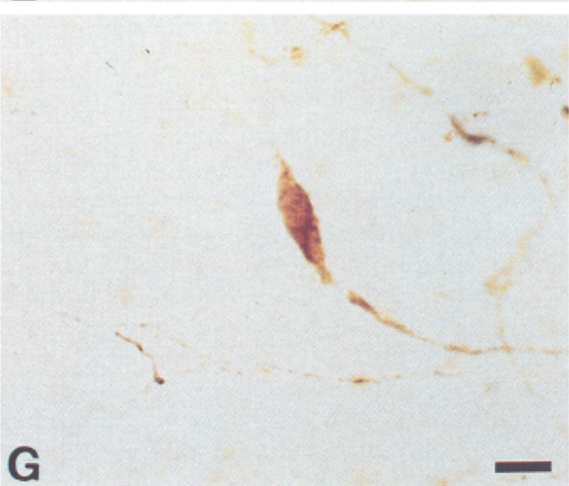

in the intracellular-encoding domain of trkC mRNA (Valenzuela et al., 1993); the antisense RNA probe was transcribed from a cDNA template subcloned into the pBluescript SK-vector. For each probe, hybridization controls consisted of tissue sections hybridized in the same assay with sense RNAs transcribed from the same cDNA templates used to synthesized the antisense probes.

\section{Hypothalamic cultures}

Hypothalami from $18 \mathrm{~d}$ old rat fetuses were mechanically dissociated using a Stomacher 80 blender (Tekmar Company, Cincinnati, OH) (1 min at $90 \%$ power) and seeded on eight-well Lab-Tek plastic culture chamber slides (Nunc, Inc., Napperville, IL) coated with polyornithinelaminin. For the coating, each chamber was treated overnight with polyornithine diluted in $15 \mathrm{~mm}$ borate buffer, $\mathrm{pH} 8.4$, at $100 \mu \mathrm{g} / \mathrm{ml}$ (Edgar et al., 1984). Following extensive washing to remove unpolymerized polyornithine, the chambers were treated with laminin at $2 \mu \mathrm{g} / \mathrm{ml}$ in PBS for $2 \mathrm{hr}$ at room temperature (Manthorpe et al., 1983). After drying, the cells were seeded at a density of 50,000 cells per well in DMEM-F12 medium containing $7.5 \%$ fetal calf serum (Hyman et al., 1991). After an overnight culture, the medium was replaced by serumfree medium supplemented with L-glutamine ( $2 \mathrm{mM})$, human transferrin
$(100 \mu \mathrm{g} / \mathrm{ml})$, putrescine $(100 \mu \mathrm{M})$, sodium selenite $(30 \mathrm{nM})$, and insulin $(5 \mu \mathrm{g} / \mathrm{ml})$ and the culture was continued for 6 more days, with one medium change $3 \mathrm{~d}$ after the addition of the serum-free medium. BDNF, NT-3, NGF, TGF $\alpha$, or EGF (50 ng/ml each) were added on the day of plating and replenished twice, at the time of initiating the culture in chemically defined medium and $3 \mathrm{~d}$ later. On day 6 , the cultures were fixed in $4 \%$ paraformaldehyde-PBS $\mathrm{pH} 7.4$ for $30 \mathrm{~min}$ at room temperature and processed for combined immunohistochemical detection of TH and p75-NGFR (see above). Following completion of the immunohistochemical reactions, immunopositive cells were counted in each well and classified as either TH-, p75-NGFR-, or TH/p75-NGFR positive. To assess the viability of the cultures, phase-contrast photomicrographs were usually taken on day 6 . In addition, the neuronal composition of the cultures was immunohistochemically assessed by the identification of NSE-positive cells.

NGF, purified from mouse submandibular gland, was kindly provided by Dr. Eugene Johnson (Washington University School of Medicine, St. Louis, MO). Purified recombinant NT-3 and BDNF were the generous gift of Dr. George Yancopoulos (Regeneron Pharmaceuticals, New York, NY). Recombinant TGF $\alpha$ was kindly provided by Dr. Daniel Twardzick (Bristol-Meyers Pharmaceuticals, Seattle, WA) and EGF was purchased from Collaborative Research (Bedford, MA). 


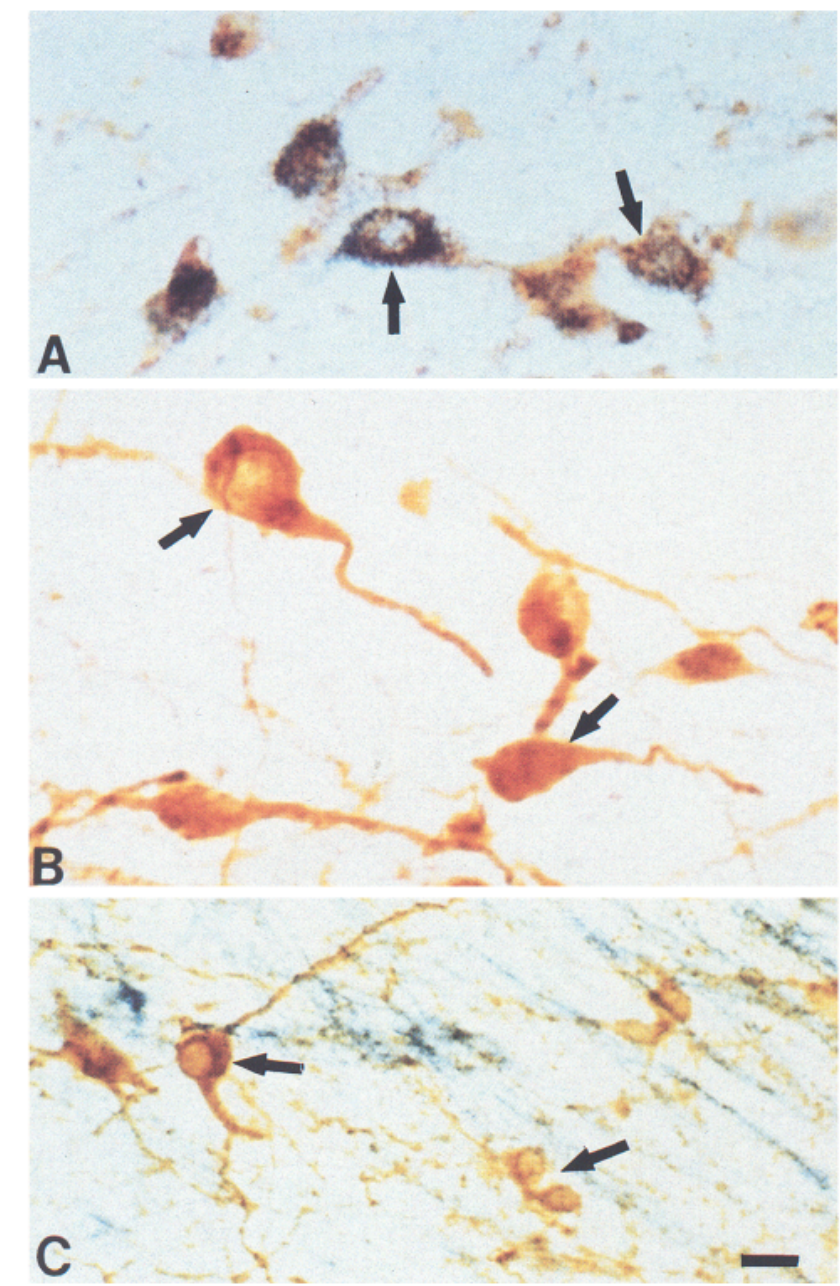

Figure 6. Double-label immunohistochemistry illustrating that some, but not all, dopaminergic neurons in the hypothalamus express the NGFR. A, Arrows show a population of TH-positive neurons (brown) in the zona incerta that are also NGFR-positive (punctate blue). $B$ and $C$, Arrows depict TH-positive neurons in both the zona incerta $(B)$ and the arcuate nucleus $(C)$ that are NGFR-negative. None of the tuberoinfundibular (arcuate nucleus) DA neurons was found to be p75-NGFR positive. Scale bar, $7 \mu \mathrm{m}$.

\section{Statistics}

The effect of different growth factors on neuronal survival was analyzed using a one-way analysis of variance followed by the Student-NeumanKeuls multiple comparison test for unequal replications.

\section{Results}

\section{Localization of p75-NGFR protein in the forebrain and hypothalamus}

Figure 1 depicts the immunohistochemical distribution of neurons expressing $\mathrm{p} 75-\mathrm{NGFR}$ in the forebrain and hypothalamus of immature female rats. The majority of these p75-NGFR-positive neurons were localized to the more rostral sections containing the diagonal band of Broca (Figs. 1A, 2A) and the medial and lateral preoptic areas (Fig. $1 B$ ). Positive cells were also seen scattered within the para- and periventricular regions of the rostral hypothalamus (Fig. 1C). More circumscribed groups of p75NGFR-positive neurons were detected in the ventrolateral hypothalamic area of the intermediate region of the hypothalamus and in the zona incerta of the dorsal hypothalamus (Fig. 1D). p75-NGFR was identified on the soma of these neurons, as well as on their unipolar, bipolar or multipolar processes (Fig. 2B,C). In the tuberoinfundibular area, intense staining was observed on the ependymal (tanycyte) cells lining the third ventricle, as well as on some of their processes within the median eminence, but not in neurons (Fig. 2D). Additionally, nerve fibers bearing p75NGFR immunoreactivity were observed in all regions studied.

\section{Localization of p75-NGFR $m R N A$ and trkA $m R N A$ in the forebrain and hypothalamus}

Hybridization histochemistry using p75-NGFR and trkA antisense RNA probes verified the ability of these probes to detect p75-NGFR and trkA mRNAs in magnocellular neurons of the diagonal band of Broca, which was used as a positive control region (Figs. $3 A, 4 A$, respectively). p75-NGFR mRNA was also found in a subset of neurons of the zona incerta (Fig. $3 B$ ), suggesting that the immunoreactive p75-NGFR material detected in neurons of this region (Figs. $1 D, 2 B$ ) indeed corresponds to the protein product of the p75-NGFR gene. In contrast, none of the neurons of the zona incerta expressed detectable levels of trkA mRNA (not shown). A similar situation was observed in the periventricular region; while some cells scattered along the walls of the third ventricle were found to be p75-NGFR mRNA positive, no trkA mRNA-containing cells were detected in the same region.

A subset of neurons, detected in the same area of the ventrolateral hypothalamus that contains p75-NGFR immunoreactive cells (Fig. 1D), was found in adjacent sections to express both p75-NGFR mRNA (Fig. 3C) and trkA mRNA (Fig. 4B), suggesting that these cells are sensitive to NGF. In contrast to the correspondence between p75-NGFR immunoreactive material and p75-NGFR mRNA expression observed in neurons of the zona incerta, periventricular area and lateroventral hypothalamus, the intense p75-NGFR immunoreactivity detected in tanycytes of the median eminence (Fig. 2D), was not accompanied by significant p75-NGFR mRNA hybridization (Fig. 3D). This discrepancy was previously noted by others (Koh et al., 1989). Tanycytes also appeared devoid of trkA mRNA (Fig. 4C).

\section{Identification of specific neuronal phenotypes expressing p75- NGFR}

Using double-label immunohistochemistry we identified specific types of neurons in the forebrain and hypothalamus that bear NGFR. For a positive control, we confirmed the presence of p75-NGFR-bearing neurons containing choline acetyltransferase (CAT) immunoreactivity within the diagonal band of Broca, as described previously (Koh and Loy, 1988). These CAT-positive neurons were often found intermingled among other p75-NGFRpositive neurons which were CAT-negative (Fig. $5 A$ ).

With regard to peptidergic neurons, some, but not all, galanin (GAL)-containing neurons in the paraventricular nucleus were NGFR-positive (Fig. 5B). Interestingly, a population of interleukin- $1 \alpha$ (IL-I $\alpha$ )-containing neurons, which share the same anatomical distribution with NGFR-positive neurons in the extreme lateral preoptic area, were observed to be p75-NGFR negative (Fig. 5C). Neuropeptide Y (NPY)-positive neurons in the cortex were found to express NGFR (Fig. 5D), whereas those NPY neurons within the arcuate nucleus of the hypothalamus did not (Fig. 5E). Furthermore, while a subpopulation of luteinizing hormone-releasing hormone (LHRH)-containing neurons in the medial septum (Fig. 5F), diagonal band of Broca and around the organum vasculosum of the lamina terminalis were p75-NGFR 

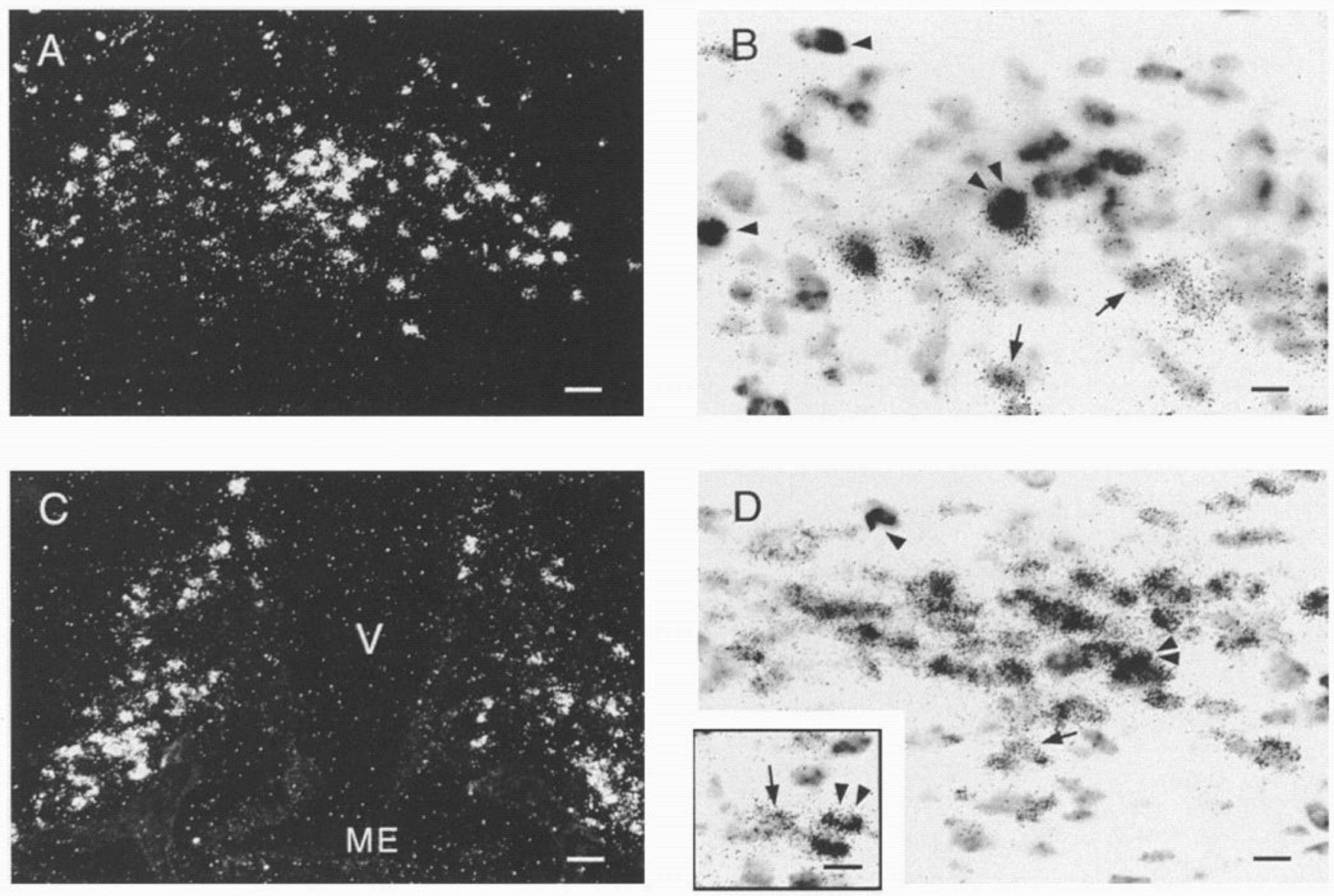

Figure 7. Detection of the messenger RNAs encoding trkB (the receptor for BDNF) and trkC (the receptor for NT-3) in hypothalamic dopaminergic neurons by double hybridization histochemistry. The two main groups of hypothalamic dopaminergic neurons, located either in the zona incerta $(A)$ or arcuate nucleus $(C)$ were identified by the detection of TH mRNA, utilizing a ${ }^{35}$ S-labeled antisense RNA probe. $B$ shows that most TH neurons of the zona incerta do not express $t r k \mathrm{C}$ mRNA. TH mRNA was detected as before; $t r k C$ mRNA was detected using a digoxygenin-labeled $c R N A$ probe complementary to the intracellular domain encoding region of trkC mRNA. Single arrows, cells expressing only TH mRNA; single arrowheads, cells expressing only trkC mRNA; double arrowheads, cell coexpressing TH and trkC mRNA. $D$ shows that many TH mRNA positive cells of the zona incerta express trkB mRNA. TrkB mRNA was detected with a digoxygenin-labeled cRNA probe complementary to the intracellular domain encoding sequence of trkB mRNA, while TH was again detected as before. Single arrow, TH mRNA-only expressing cells; single arrowheads, trkB mRNAonly expressing cells; double arrowheads, TH neurons coexpressing TH and $t r k \mathrm{~B}$ mRNA. Scale bars: $A$ and $C, 20 \mu \mathrm{m} ; B$ and $D, 5 \mu \mathrm{m}$.

positive, other LHRH neurons within this region were devoid of the receptor (Fig. 5G).

\section{p75-NGFR is differentially expressed in two regionally segregated groups of dopaminergic neurons}

The hypothalamus contains four groups of dopaminergic neurons; of these, the major two groups are located in the tuberoinfundibular-arcuate nucleus region and the zona incerta, respectively (Björklund and Nobin, 1973; Björklund et al., 1975). The third group, located in the rostral hypothalamus, is less well defined as it is composed of cells scattered along the periventricular region (Björklund and Nobin, 1973; Björklund et al., 1975). The fourth group extends from the dorsal hypothalamus to the caudal thalamus. According to the nomenclature proposed by Fuxe et al. (1969), these neuronal subsets are referred to as groups A13 (zona incerta), A12 (arcuate nucleus), A14 (rostral periventricular group), and A11 (caudal hypothalamic-thalamic group). They can be readily identified by immunohistochemical detection of TH (Fig. 6) or by in situ hybridization using probes that recognize TH mRNA (Fig. 7A,C).

We found that NGFR is differentially expressed in the two major DA groups of the hypothalamus. In the zona incerta some of the TH-positive neurons were found to also be p75-NGFR positive (Fig. $6 A$ ), whereas other $\mathrm{TH}$ neurons in this area were p75-NGFR negative (Fig. $6 B$ ). Conversely, in the tuberoinfundibular region none of the TH-positive neurons in the arcuate nucleus contained p75-NGFR immunoreactivity (Fig. 6C).

\section{Differential expression of trkB and trkC mRNAs in dopaminergic neurons of the zona incerta and tuberoinfundibular regions}

Double in situ hybridization revealed that while a few $\mathrm{TH}$ mRNA-positive neurons in the zona incerta contain trkC mRNA (Fig. 7B, double arrowheads), most TH mRNA-expressing neurons do not appear to express the $t r k \mathrm{C}$ gene (Fig. $7 \mathrm{~B}$, arrows). Some trkC mRNA-containing neurons were TH mRNA-negative (Fig. $7 B$, single arrowhead). In contrast, a substantial fraction of DA neurons of the zona incerta exhibit readily detectable levels of $t r k \mathrm{~B}$ mRNA (Fig. $7 D$, double arrowheads). Nevertheless, not all TH mRNA-containing neurons in this region express trkB mRNA (Fig. 7D, arrow), and some trkB mRNA-positive neurons did not contain TH mRNA (Fig. $7 D$, arrowhead). The inset depicts adjacent neurons containing only TH mRNA (arrow) or both $\mathrm{TH}$ and $t r k \mathrm{C}$ mRNAs (double arrowhead). 

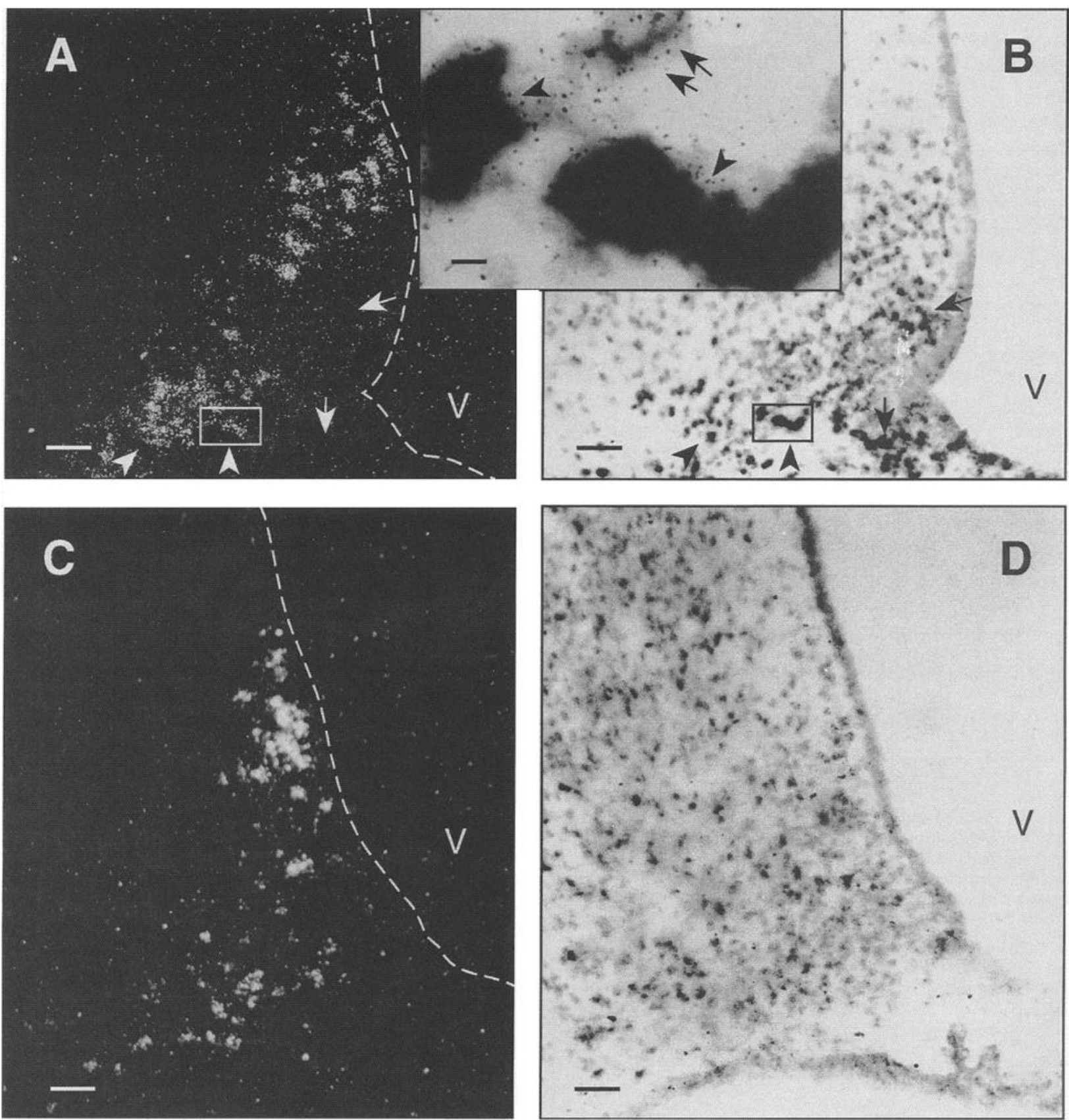

Figure 8. Differential expression of trkB and trkC mRNAs in DA neurons of the tuberoinfundibular region. A, TH mRNA-positive cells shown using dark-field illumination. $B$, The same section depieted in $A$ shows under bright-field illumination that some TH mRNA-positive cells in the ventral portion of the arcuate nucleus (arrowheads in $A$ and $B$ ) also contain trkC mRNA. Other trkC mRNA-containing neurons are TH mRNAnegative (arrows in $A$ and $B$ ) (scale bars, $20 \mu \mathrm{m}$ ). The inset is an enlargement of the boxed area in $A$ and $B$ and shows at a higher magnification TH mRNA positive cells expressing trkC mRNA (arrowheads) and TH mRNA positive cells devoid of trkC mRNA (double arrow) (scale bar, 2 $\mu \mathrm{m}) . C$, A different section of the median eminence-arcuate nucleus depicting TH mRNA-containing neurons. $D$, The same section depicted in $C$ shows under bright-field illumination the absence of detectable trkB mRNA in tuberoinfundibular TH mRNA-positive cells (scale bars, $20 \mu \mathrm{m}$ ).

In marked contrast with the zona incerta, the vast majority of dopaminergic neurons of the tuberoinfundibular-arcuate region had undetectable levels of trkB mRNA (Fig. 8C,D). Some of them, however, particularly those more ventrally located exhibited $t r k C$ mRNA hybridization signal (Fig. 8A, $B$, inset).

\section{$B D N F$ enhances the survival of p75-NGFR containing dopaminergic neurons in culture}

To determine the physiological importance of the differential expression of $t r k$ receptors in hypothalamic DA neurons, we treated hypothalamic cultures with different neurotrophins, including NGF, BDNF, and NT-3. TGF $\alpha$ and EGF were also tested in consideration of the finding that both growth factors have been shown to be trophic for mesencephalic dopaminergic neurons (Casper et al., 1991; Alexi and Hefti, 1993). The results demonstrated that BDNF facilitates the survival of TH neurons expressing p75-NGFR, but not of those devoid of p75-NGFR (Fig. 9). Thus, BDNF may be predominantly trophic for A13 DA neurons of the zona incerta since these cells represent the major group of hypothalamic DA neurons expressing the $\operatorname{trkB}$ 


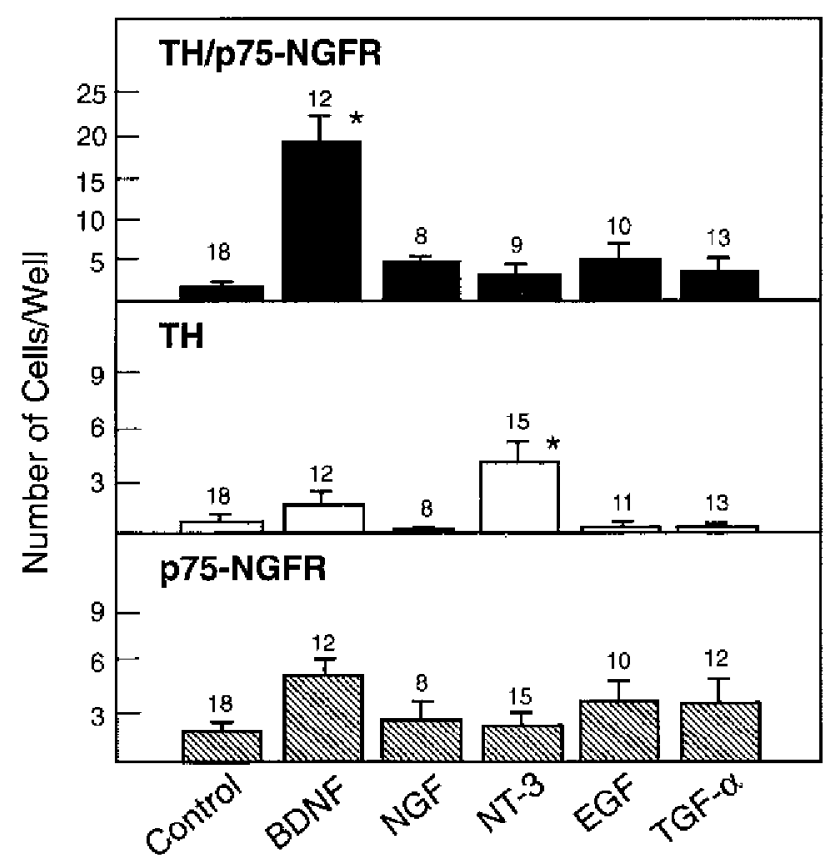

Figure 9. Effect of brain derived neurotrophic factor (BDNF) and neurotrophin 3 (NT-3) on the survival of bypothalamic dopaminergic neurons in culture. Hypothalami from 18 d old rat fetuses were mechanically dissociated and seeded on eight well $\mathrm{T}$ ab-Tek plastic culture chamber slides (Nunc Inc.) at a density of 50,000 cells per well in DEEMF12 medium containing $7.5 \%$ fetal calf serum. After overnight culture, the medium was replaced by a serum-free medium (see Materials and Methods) containing the different growth factors tested (each at $50 \mathrm{ng} /$ ml) and the culture was continued for 6 more days, with one medium change and growth factor replenishlunent $3 \mathrm{~d}$ after addition of the serumfree medium. On day 6 , the cultures were fixed in $4 \%$ paraformaldehyde-PBS pH 7.4 (30 min at room temperature) and processed for combined immunohistochemical detection of tyrosine hydroxylase $(\mathrm{TH})$ and the low-affinity nerve growth factor receptor $(p 75-N G F R)$. TH/p 75 NGFR, Neurons immunopositive for both TH and p75-NGFR; $T H$, neurons immunopositive only for ' $\mathrm{TH} ; p 75-N G F R$, neurons immunopositive only for p75-NGFR. Numbers on top of bars are number of wells per group; *, $p<0.01$ versus control wells.

gene. Although we did not analyze the in vivo expression of trkB mRNA in Al4 rostral periventricular DA cells, they do contain p75-NGFR (Fig. 1) and thus their survival may have also been promoted by BDNF. On the other hand, the survival of TH neurons lacking p75-NGFR was facilitated, though to a lesser extent, by NT-3 (Fig. 9). Since most hypothalamic p75NGFR-negative TH neurons are located in the tuberoinfundibular region and some of them express trkC mRNA, this in vitro effect of NT-3 suggests that NT-3 may support the survival of at least a fraction of A12 DA neurons. None of the other growth factors tested had any effect on the survival of the DA neurons analyzed. Figure $10 \mathrm{~A}$ illustrates the general aspect of $6 \mathrm{~d}$ old cultures, as assessed by phase-contrast microscopy. That a substantial fraction of the total population of viable cells correspond to neurons is demonstrated by the abundance of NSE-positive cells detected in these cultures (Fig. 10B). Figure 11 shows examples of DA neurons expressing p75-NGFR and cultured in the presence of BDNF ( $A$ and $B$ ), TH-negative neurons containing p75-NGFR alone, also cultured in the presence of BDNF (C) and TH- immunopositive neurons devoid of $p 75$-NGFR, cultured in the presence of NT-3 $(D)$.

\section{Discussion}

The hypothalamus contains a great diversity of neuronal phenotypes, ranging from those that utilize classical neurotransmitters for their synaptic communications to those that secrete neuropeptides into the portal vasculature to regulate hypophyscal function. Not surprisingly, given the low prevalence of $\mathrm{p} 75$ NGFR mRNA in the hypothalamus (Koh et al., 1989; Lu et al., 1989; Ojeda et al., 1990), only some of the neuronal populations identified in the present study were found to express p75-NGFR. The finding that the receptor could be detected in only a small subset of cells within a given population of peptidergic neurons was, however, unexpected. Thus, p75-NGFR was detected in only some galanin-containing neurons of the periventricular region and a small fraction of LHRH neurons of the preoptic region. Additionally, p75-NGFR was detected in some vasoactive intestinal peptide (VIP)-containing neurons of the suprachiasmatic nucleus. Since the presence of $\mathrm{p} 75-\mathrm{NGFR}$ may facilitate and/or enhance the biological actions of neurotrophins exerted via activation of $t r k$ receptors (Berg et al., 1991; Benedetti et al., 1993; Davies et al., 1993), it may be speculated that, within each peptidergic phenotype, those neurons expressing p75NGFR may be the most responsive to a particular neurotrophin, should they have the appropriate $t r k$ receptor. Experiments to define the type of $t r k$ receptor expressed by hypothalamic $\mathrm{p} 75$ NGFR-containing peptidergic neurons and their relative responsiveness to neurotrophins are required to assess the validity of this notion.

Of the peptidergic neurons identified, those producing LHRH are the best characterized both functionally and morphologically. They play a central role in dirceting sexual development (Ojeda and Urbanski, 1994) and mature reproductive function (Silverman et al., 1994). Despite their importance, nothing is known about the trophic factors that they may require for either survival, differentiation or maintenance of their differentiated functions. Although our results clearly show the presence of p75NGFR in a subset of LHRH neurons, we can not conclude that these cells are responsive to neurotrophins. p75-NGFR is not essential for neurotrophin action (Ibánéz et al., 1992, and references therein; Jing et al., 1992), a concept derived from in vitro experiments, but supported by the lack of central neuronal deficits observed in animals carrying a targeted mutation of the p75-NGFR gene (Lee et al., 1992) and by the present finding of hypothalamic DA neurons that do not express $\mathrm{p} 75$-NGFR and yet are responsive to NT-3 (see below). In fact, neurotrophins do not appear to be trophic for embryonic LHRH neurons in culture (umpublished observations), and GTi-7 cells-a wellcharacterized LHRH neuronal cell line (Mellon et al., 1990)--..do not contain detectable levels of either $t r k \mathrm{~A}, \mathrm{~B}$, or $\mathrm{C}$ mRNA (Zhou et al., 1994, and unpublished observations). Thus, the physiological significance of the presence of $p 75-$ NGFR in a subset of LHRH neurons remains to be ascertained.

A much more conclusive picture emerged from the finding that p75-NGFR is differentially expressed in the two main groups of hypothalamic DA neurons, because in this case we were also able to demonstrate the differential expression of $t r k$ genes in these cells, as well as the ability of neurotrophins to differentially promote the survival of p75-NGFR-containing and p75-NGFR-devoid hypothalamic DA cells in culture. The hypothalamus contains four DA cell groups (Björklund and Nobin, 1973): a rostral periventricular group (A14) composed of cells scattered in the periventricular region and extending from the 


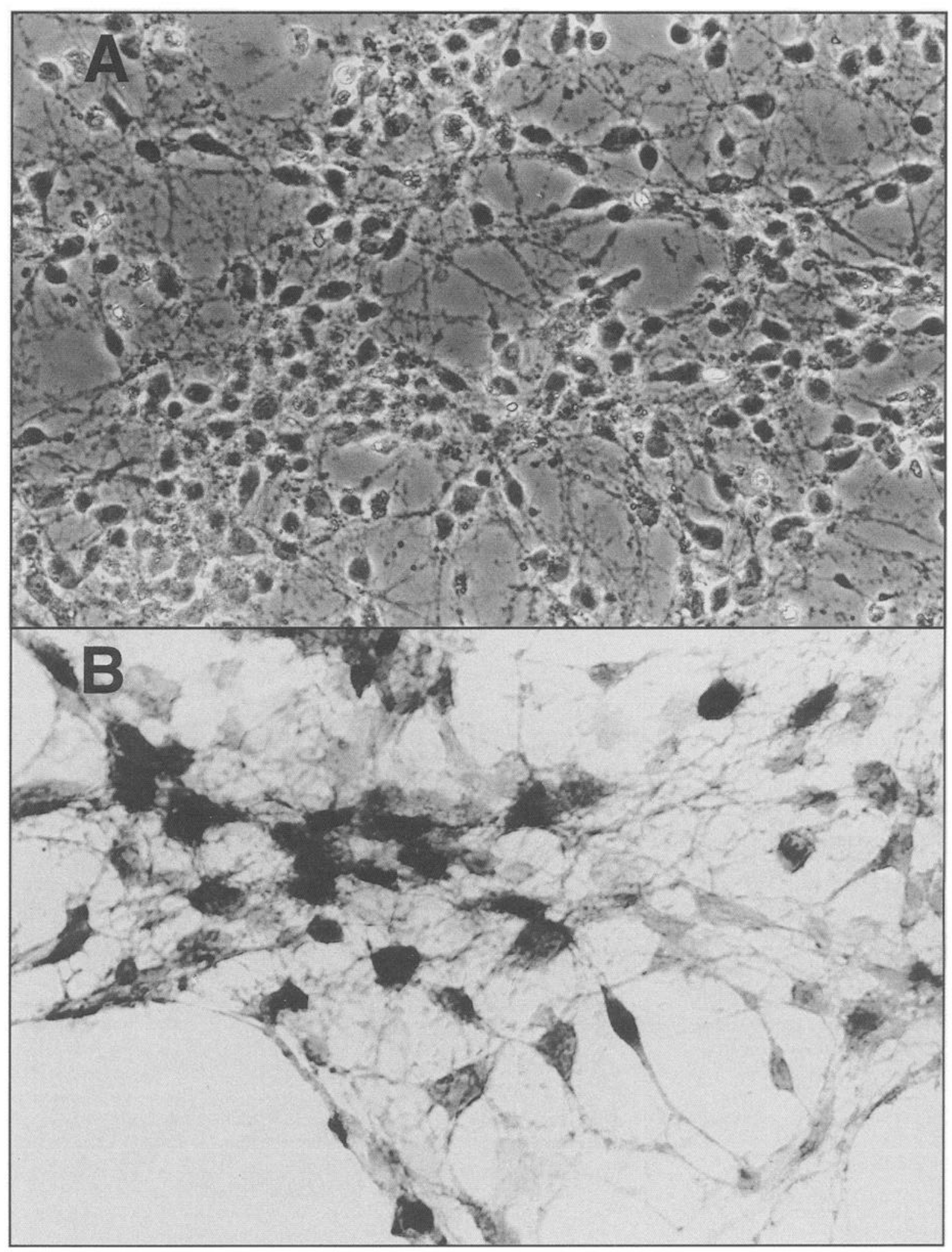

Figure 10. A, Phase-contrast photomicrograph of a typical hypothalamic culture prepared from $18 \mathrm{~d}$ old rat fetuses, after $6 \mathrm{~d}$ in neuronal defined medium. Notice the presence of numerous neuron-like cells and their extensive arborization (159 $\times)$. $B$, Immunohistochemical identification of NSEpositive cells demonstrates the presence of a substantial number of neurons in the same cultures $(1080 \times)$.

level of the anterior commissure to the rostral border of the median eminence, a cell group located in the arcuate nucleus (A12) that constitute the tuberoinfundibular dopaminergic system, a dorsal group (A13) which is located in the medial zona incerta, and a caudal group (A11), which contains both DA and noradrenergic neurons and extends diffusely from the posterior hypothalamic area to the caudal thalamus (Björklund and Nobin, 1973; Björklund et al., 1975). Of these four groups, the DA 

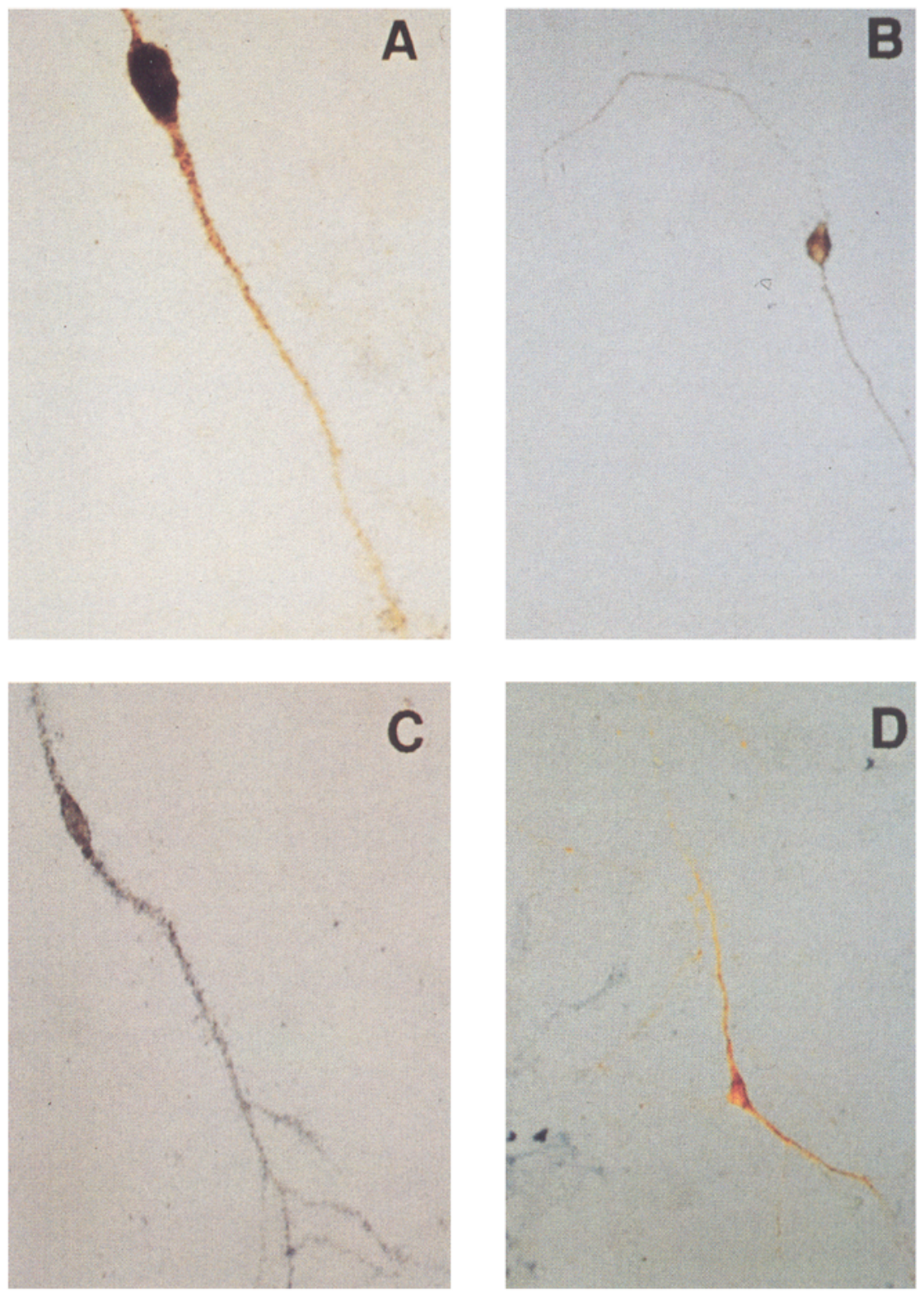

Figure II. Representative hypothalamic neurons in culture expressing either both TH and p75-NGFR immunoreactivities $(A, B)$, only p75-NGFR $(C)$ or only TH $(D)$. TH immunoreactivity has a brown color and smooth appearance. p75-NGFR immunoreactivity has a blue color and a crystal-like appearance. The neurons depicted correspond to cultures treated with BDNF $(A-C)$ or NT-3 $(D)$. All panels, 1560×. neurons of the zona incerta and arcuate nucleus are the most prominent, not only because they are anatomically more circumscribed (Björklund and Nobin, 1973; Björklund et al., 1975), but also because there is a greater knowledge of the functions in which they are involved. Tuberoinfundibular DA neurons play a fundamental role in the control of prolactin release from the anterior pituitary (Neill and Nagy, 1994). They release DA into the hypothalamic portal vasculature, which then transport the catecholamine to the pituitary gland where it directly affects hormone secretion (Kordon et al., 1994; Neill and Nagy, 1994). Dysfunction of the tuberoinfundibular DA system results in unrestricted prolactin secretion (hyperprolactinemia) and infertility. Since tuberoinfundibular DA neurons also regulate the secretion of other pituitary hormones such as gonadotropins and growth hormone (Reichlin, 1985; Fink, 1988), it is clear that they play an important role in both reproductive function and somatic development.

The zona incerta, on the other hand, is involved in a wider spectrum of activities as neurons in this region contribute to the control of food and water intake (Rowland et al., 1979; Brown and Grossman, 1980; Dalton and Grossman, 1982), nociception (Kaelber and Smith, 1979), visual discrimination (Legg, 1979), sexual behavior (Wilson et al., 1991) and gonadotropin release (McKenzie et al., 1984; Sanghera et al., 1991; Wilson et al., 1991). This diversity of functions is, in fact, predicted by the complexity of the terminal fields innervated by zona incerta DA neurons, as they project diffusely to the anterior and dorsal hypothalamic areas, the dorsomedial nucleus of the hypothalamus and the posterior hypothalamus (Björklund et al., 1975; Ricardo, 1981). In contrast to A13 and A12 groups of DA neurons, not much is known about the functions of the rostral A14 and the caudal A11 groups, perhaps because of their more scattered distribution. While the caudal A11 group projects to the spinal cord, the rostral Al4 group innervates the preoptic area, the periventricular region, the suprachiasmatic nucleus, and the lateral septal nucleus (Björklund et al., 1975).

In the present study we observed a striking difference in neurotrophin receptor expression consisting of the absence of p75- 
NGFR in tuberoinfundibular A12 neurons as opposed to the rostral A14 and dorsal A13 groups, in which both immunoreactive p75-NGFR protein and p75-NGFR mRNA were detected. Clearly, however, not all zona incerta A13 or rostral Al4 DA neurons express p75-NGFR, suggesting that cellular diversity of neurotrophin receptor genc expression in the hypothalamus occurs even in spatially circumscribed neuronal groups, which-because of their common localization and neurotransmitter phenotype-may be anticipated to originate from the same progenitor cells. Interestingly, this diversity is not limited to p75$\mathrm{NGFR}$, as it is also prominent for $t r k \mathrm{~B}$ and $t r k \mathrm{C}$ receptors. As in the case of p75-NGFR, zona incerta DA neurons, but not tuberoinfundibular A12 DA neurons, express $t r k B$ mRNA. Also, trkB mRNA was not detected in all zona incerta DA neurons. The pattern of expression of $t r k \mathrm{C}$ is more complex since $t r k \mathrm{C}$ mRNA was seen in some zona incerta DA neurons, as well as in some of the most ventrally located tuberoinfundibular DA neurons. We did not analyze the expression of $t r k$ receptor genes in the rostral A14 group of DA cells, but noticed occasional expression of $t r k \mathrm{~B}$ mRNA in these cells.

The in vitro experiments clearly demonstrate that DA cellsidentified by their TH immunoreactivity-respond differently to BDNF or NT-3, according to the presence of absence of p75NGFR. Thus, BDNF selectively enhances the survival of TH/ p75-NGFR-positive cells, whereas NT-3 has no effect on these cells, but exhibits a significant survival promoting effect on $\mathrm{TH}$ cells devoid of p75-NGFR. Consistent with the absence of in vivo expression of trkA in hypothalamic DA neurons, no survival or trophic effect of NGF on $\mathrm{TH}$ immunoreactive neurons was detected in culture, indicating that, as shown for mesencephalic DA neurons (Knüscl ct al., 1991; Hyman et al., 1994), hypothalamic DA neurons do not require NGF for survival.

It would be difficult to argue that the presence or absence of p75-NGFR determines the responsiveness of DA cells to BDNF or NT-3. One can assume, however, that TH/p75-NGFR positive cells in culture correspond to DA cells of the A13 zona incerta/ Al4 rostral group and that TH positive/p75-NGFR negative in vitro mainly refiect the A12 tuberoinfundibular group detected in vivo. Based on this correspondence, the in vitro results argue in favor of the notion that BDNF supports the survival of A13 and perhaps A14 DA neurons, whereas NT-3 is trophic for both the subsets of A13 zona incerta and A12 tuberoinfundibular DA neurons expressing the $t r k \mathrm{C}$ gene. This view is not only consistent with the observation that mesencephalic DA neurons expressing p75-NGFR are responsive to BDNF (Hyman et al., 1991), but may also provide an explanation for the conflicting observations concerning the responsiveness of these neurons to NT-3 (Knüsel et al., 1991; Hyman et al., 1994). If mesencephalic DA neurons are as heterogeneous in their sensitivity to neurotrophins as their hypothalamic counterparts, detection of selective NT-3 effects will depend on the size of the subset of cells bearing $t r k \mathrm{C}$ receptors.

The presence of BDNF in the anterior hypothalamus, preoptic area and ventromedial nucleus (Friedman et al., 1991), which contain terminal fields for the A13 zona incerta and Al4 rostral DA neurons suggest that these regions have target cells involved in supporting the survival and differentiated functions of A13 and A14 DA groups. In turn, the reported involvement of the zona incerta in feeding behavior (Kendrick and Baldwin, 1986; Rowland et al., 1979; Brown and Grossman, 1980) and the observation that mice with a null mutation of the $t r k \mathrm{~B}$ gene do not display feeding behavior (Klein et al., 1993), suggest that trkB receptors are important for the development and maintenance of hypothalamic zona incerta DA neurons.

In a broader context, our results suggest that survival of neurons with an identical neurotransmitter phenotype and located within the same brain region or even within the same cellular group, is not determined by the same intercellular signalling events. It rather appears that "identical" neurons may follow different developmental options, which specify the class of trophic molecules the cells will require to survive. Since an obvious difference among regionally circumscribed neurons of identical phenotypes resides in the targets they innervate, it is conceivable that target cells themselves play a role in determining the type of neurotrophic receptor expressed by the innervating neurons. The molecular processes underlying this induction may be similar to those by which cells of an "cquivalent" group become committed to a particular identity in response to signals provided by cells that are not part of the group (Greenwald and Rubin, 1992). Manifestation of this heterogeneity in trophic signal dependency would maximize the functional integrity of particular subsets of innervating-target neurons. On the other hand, loss of trophic support to a subset of neurons within a group endowed with the same neurotransmitter phenotype would only lead to the death of those neurons affected, without compromising other functions exerted by the rest of the group. Such a safety mechanism may be especially important for neuronal groups with such diverse functions as the DA neurons of the tuberoinfundibular region and zona incerta of the hypothalamus.

\section{References}

Alderson RF, Alterman AL, Barde YA, Lindsey RM (1990) Brainderived neurotrophic factor increases survival and differentiated functions of rat septal cholinergic neurons in culture. Neuron 5:297-306.

Alexi T, Hefti F (1993) Trophic actions of transforming growth factor $\alpha$ on mesencephalic dopaminergic neurons developing in culture. Neuroscience 55:903-918.

Barbacid M, Lamballe I; Pulido D, Klein R (1991) The trk family of tyrosine protein kinase receptors. Biochim Biophys Acta 1072:115127.

Benedetti M, Levi A, Chao MV (1993) Differential expression of nerve growth factor receptors leads to altered binding affinity and neurotrophin responsiveness. Proc Natl Acad Sci USA 90:7859-7863.

Berg MM, Sternberg DW, Hempstead BL, Chao MV (1991) The lowaffinity p75 nerve growth factor (NGF) receptor mediates NGF-induced tyrosine phosphorylation. Proc Natl Acad Sci USA 88:71067110.

Berkemeier LR, Winslow JW, Kaplan DR, Nikolics K, Goeddel DV, Rosenthal A (1991) Neurotrophin-5: a novel neurotrophic factor that activates trk and trkB. Neuron 7:857-866.

Björklund A, Nobin A (1973) Fluorescence histochemical and microspectrofluorometric mapping of dopamine and noradrenaline cell groups in the rat diencephalon. Brain Res 51:193-205.

Björklund A, Lindvall O, Nobin A (1975) Evidence of an incertohypothalamic dopamine neurone system in the rat. Brain Res 89:2942.

Bothwell M (1991) Keeping track of neurotrophin receptors. Cell 65: 915-918.

Brown B, Grossman SP (1980) Evidence that nerve cell bodies in the zona incerta influence ingestive behaviour. Brain Res Bull 5:593-597.

Buck CR, Martinez HJ, Chao MV, Black IB (1988) Differential expression of the nerve growth factor receptor gene in multiple brain areas. Dev Brain Res 44:259-268.

Casper D, Mytilineou C, Blum M (1991) EGF enhances the survival of dopamine neurons in rat embryonic mesencephalon primary cell culture. J Neurosci Res 30:372-381.

Chandler CE, Parsons LM, Hosang M, Shooter EM (1984) A monoclonal antibody modulates the interaction of nerve growth factor with PC12 cells. J Biol Chem 259:6882-6889.

Collazo D, Takahashi H, McKay RDG (1992) Cellular targets and tro- 
phic functions of neurotrophin-3 in the developing rat hippocampus. Neuron 9:643-656.

Dalton LD, Grossman SP (1982) Responses to dietary adulterations in rals with zona incerta lesioms. Physiol Behlav 29:51-60.

Davies AM, Lee K-F, Jaenisch R (1993) p75-Deficient trigeminal sensory neurons have an altered response to NGF but not to other neurotrophins. Neuron [ 1:565-574

Dees WL, Berg-von der Emde K, Hiney JK, Hill DF, Dissen GA, Ojeda SR (1993) Brain-derived neurotrophic factor (BDNF) selectively promotes the survival of hypothalamic dopaminergic (DA) neurons expressing low-affinity nerve growth factor receptors (NGFR). Soc Neurosci Abstr 19:249.

Dissen GA, Hill DF, Costa ME, Ma YJ, Ojeda SR (1991) Nerve growth factor receptors in the peripubertal rat ovary. Mol Endocrifol 5:16421650

Edgar D, Timpl R, Thoenen $H$ (1984) The heparin-binding domain of laminin is responsible for its effects on neurite outgrowth and neuronal survival. EMBO J 3:1463-1468.

Ernfors P, Ibañez CF, Ebendal T, Olson L, Persson H (1990) Molecular cloning and neurotrophic activities of a protein with structural similarities to nerve growth factor; developmental and topographical ex pression in the brain. Proc Natl Acad Sci USA 87:5454-5458.

Fink G (1988) Gonadotropin secretion and its control. In: The physiology of reproduction, 1 st ed, Vol 1 (Knobil E, Neill J, eds), pp 13491377. New York: Raven.

Friedman WJ, Olson L, Persson H (1991) Cells that express brainderived neurotrophic factor mRNA in the developing postnatal rat brain. Eur J Neurosci 3:688-697.

Fuxe K, Hokfelt T, Ungerstedt U (1969) Distribution of momoumines in the mammalian central nervous system by histochemical studies. In: Metabolism of amines in the brain (Hooper $\mathrm{G}$, ed), pp 10-22. London: Macmillan.

Gonzalez. D, Dees WL, Hiney IK, Ojeda SR, Saneto RP (1990) Ex pression of $\beta$-nerve growth factor in cultured cells derived from the hypothalamus and cerebral cortex. Brain Res 511:249-258.

Greenwajd I, Rubin GM (1992) Making a difference: the role of cellcell interactions in establishing separate identities for equivalent cells Cell 68:271-281

Grima B, Lamouroux A, Blanot F, Faucon Bjguet N, Mallet J (1985) Complete coding sequence of rat tyrosine hydroxylase mRNA. Proc Natl Acad Sci USA 82:617-621.

Hallböok F, lbañez CF, Persson H (1991) Evolutionary studies of the nerve growth factor fanily reveal a novel member abundantly expressed in Xenopui ovary. Neuron 6:845-858.

Hefti $F$ (1986) Nerve growth factor promotes survival of septal cholinergic neurons after fimbrial transections. J Neurosci 6:2155-2162.

Hempstead BL, Martin-Zanca D, Kaplan DR, Parada LF, Chao MV (1991) High-affinity NGF binding requires coexpression of the $t h$ proto-oncogene and the low-affinity NGF receptor. Nature 350:678683.

Hohn A, Leibrock J, Bailey K, Barde Y (1990) Identification and char acterization of a novel member of the nerve growth factor/brainderived neurotrophic factor family. Nature 344:339-341.

Holzman DM, Li Y, Parada LF, Kinsman S, Chen C-K, Valtetta JS, Zhou J, Long JB, Mobley WC (1992) p140 irk mRNA marks NGFresponsive forebrain neurons: evidence that $t r k$ gene expression is induced by NGF. Neuron 9:465-478.

Hyman C, Hofer M, Barde Y, Juhasz M, Yancopoulos GD, Squinto SP, Lindsay RM (1991) BDNF is a neurotrophic factor for dopaminergic neurons of the substantia nigra. Nature 350:230-232.

Hyman C. Juhasz M, Jackson C. Wright P, Ip NY. Lindsay RM (1994) Overlapping and distinct actions of the neurotrophins BDNF, NT-3, and NT-4/5 on cultured dopaminergic and GABAergic neurons of the ventral mesencephalon. J Neurosci 14.335-347.

Ibáñez CF, Ebendal T, Barbany G, Murray-Rust J, Blundell TL, Persson $\mathrm{H}$ (1992) Disruption of the low affinity receptor-binding site in NGF allows neuronal survival and differentiation by binding to the $t r k$ gene product. Cell 69:329-341.

Ip NY, Ibañez CF, Nye SH, McClain J, Jones PF, Gies DR, Belluscio L, Le Beau MM, Espinosa R III, Squinto SP, Persson H, Yancopoulos GD (1992) Mammalian neurotrophin-4: structure, chromosomal localization, tissue distribution, and receptor specificity. Proc Natl Acad Sci LISA $89: 3060-3064$

Ip NY, Stitt TN, Tapley P, Klein R, Glass DJ, Fandl J, Greene LA, Barbacid M, Yancopoulos GD (1993) Similarities and differences in the way neurotrophins interact with the trk receptors in neuronal and nonneurona] cells. Neuron 10:137-149.

Jing S, Tapley P, Barbacid M (1992) Nerve growth factor mediates signal transtuction through trk homodimer receptors. Neuron 9:1067-1079

Junier M, Ma YJ, Costa ME, Hoffman G, Hill DF, Ojeda SR (1991) lransforming growth factor alpha contributes to the mechanism by which hypothalamic injury induces precocious guberty. Proc Natl Acad Sci USA 88:9743-9747.

Kaelber WW, Smith TB (1979) Projections of the zona incerta in the cat, with stimulation controls. Exp Neurol 63:177-200.

Kaplan DR, Hempsead BI, Martin-7anca D, Chan MV, Parada L_F (1991) The $t r k$ proto-oncogene product: a signal transducing receptor for nerve growth factor. Science 252:554-558

Kondrick KM, Baldwin BA (1986) Characterisation of neuronal responses in the zona incerta of the subthalamic region of the sheep during ingestion of food and liquid. Neurosci Lett 63:237-242.

Ktein R, Martin-Zanca D, Barbacid M, Parada LF (1990) Expression of tyrosine kinase receptor gene $t r k B$ is confined to the murine embryonic and adult nervous svstem. Development 109:845-850.

Klein R, Jing $\mathrm{S}$, Nanduri $\mathrm{V}$, O'Rourke $\mathrm{E}$, Barbacid $\mathrm{M}$ (1991) The trk proto-oncogene encodes a receptor for nerve growth factor. Celf 65: $189-197$.

Klein R, Lamballe F, Bryant $\mathrm{S}$, Barbacid $\mathrm{M}$ (1992) The trkB tyrosine protein kinase is a receptor for neurotrophin-4. Neuron 8:947-956.

Klein R, Smeyne RJ, wurst W, Long LK, Auerbach BA, Joyner AL, Barbacid M (1993) Targeted distuption of the $t / k B$ neurotrophin receptor gene results in nervous system lesions and neonatal death. Cell $75: 113-122$

Knïsel B, Winslow JW, Rosenthal A, Burton LE, Seid DP, Nikolics K Hefti $\mathrm{F}$ (1991) Promotion of central cholinergic and dopaminergic neuron differentiation by brain-derived neurotrophic factor but not neurotrophin 3. Proc Natl Acad Sci USA 88:961-965.

Koh S, Loy R (1988) Age-related loss of nerve growth factor sensitivity in tat basal forebrain neurons. Brain Res 440:396-401.

Koh S, Oyler GA, Higgins GA (1989) Localization of nerve growth factor receptor messenges RNA and protein in the adult rat brain Exp Neurol 106:209-221.

Kordon C, Drouva SV, Martinez de la Escalera G, Weiner RI (1994) Role of classic and peptide neuromediators in the ncurocndocrinc regulation of luteinizing hormone and prolactin. In: The physiology of reproduction, $2 \mathrm{~d}$ ed, Vol 1 (Knobil E, Neill JD, eds), pp 16211681. New York: Raven.

Korsching S, Auburger G, Heumann R, Scott J, Thoenen H (1985) Levels of nerve growth factor and its mRNA in the central nervous system of the rat correlate with cholinergic innervation. EMBO J 4:1389-1393.

Lamballe F, Klein R, Barbacid M (1991) trkC a new member of the irk family of tyrosine protein kinases, is a receptor for neurotrophin3. Cell 66:967-979

Lamballe F, Smeyne RJ, Barbacid M (1994) Developmental expression of $t r k \mathrm{C}$, the neurotrophin-3 receptor, in the mammalian nervous system. J Neurosci 14: 14-28.

Lee K, Li E, Huber LJ, Landis SC, Sharpe AH, Chao MV, Jaenisch R (1992) Targeted mutation of the gene encoding the low affinity NGF receptor p75 leads to deficits in the peripheral sensory nervous system. Cell 69:737-749.

Legg CR (1979) Visual discrimination impairments after lesions in zona incerta or lateral terminal nucleus of accessory optic tract. Brain Res 177:461-478.

Leibrock J, Lottspeich F Hohn A, Hofer M, Hengerer B, Masiakowski $\mathrm{P}$, Thoenen H, Barde $\mathrm{Y}$ (1989) Molecular cloning and expression of bran-derived neurotrophic factor. Nature $341 ; 149-152$.

Levi-Montalcini $\mathrm{R}$ (1987) The nerve growth factor 35 years later. Science $237: 1154-1162$.

Lokos J, Basbaum A (1986) Benzidine dihydrochloride as a chromogen for single- and double-label light and electron microscopic immunocytochemical studies. J Histochem Cytochem 34:1047-1056.

Lu B, Buck CR, Dreyfus CF, Bjack IB (1989) Expression of NGF and NGF receptor mRNAs in the devetoping brain: evidence for local delivery and action of NGF. Exp Neurol 104:191-199.

Maisonpierre PC. Belluscio L, Friedman B, Alderson RF, Wiegand SJ Furth ME, Lindsay RM, Yancopoulos GD (1990a) NT-3, BDNF, and NGF in the developing rat nervous system: parallel as well as reciprocal patterns of expression. Neuron 5:501-509. 
Maisonpierre PC, Belluscio L, Squinto S, Ip NY, Furth ME, Lindsay RM, Yancopoulos GD (1990b) Neurotrophin-3: a neurotrophic factor related to NGF and BDNF. Science 247:1446-1451.

Manthorpe M, Engval E, Ruoslahti E, Longo FM, Davis GE, Varon $S$ (1983) Laminin promotes neuritic regeneration from cultured peripheral and central neurons. J Cell Biol 97:1882-1890.

Marangos PJ, Schmechel DE (1987) Neuron specitic enolase, a clinically useful marker for neurons and neuroendocrine cells. Annu Rev Neurosci 10:269-295.

McKenzie FJ, Hunter AJ, Daly C, Wilson CA (1984) Evidence that the dopaminergic incerto-hypothalamic tract has a stimulatory effect on ovulation and gonadotrophin release. Neuroendocrinology 39 : 289-295.

Meakin SO, Shooter EM (1992) The nerve growth factor family of receptors. Trends Neurosci 15:323-331.

Meakin SO, Suter U, Drinkwater CC, Welcher AA, Shooter EM (1992) The rat $i r k$ protooncogene product exhibits properties characteristic of the slow nerve growth factor receptor. Proc Natl Acad Sci USA $89: 2374-2378$.

Mellon PL, Windle JJ, Goldsmith PC, Padula CA, Roberts JL, Weiner RI (1990) Immortalization of hypothalamic $\mathrm{GnRH}$ neurons by genetically targeted tumorigenesis. Neuron $5: 1-10$.

Middlemas DS, Lindberg RA, Hunter T (1991) trkB, a neural receptor protein kinase: evidence for a full-length and two truncated receptors. Mol Cell Biol 11:143-153.

Neill JD, Nagy GM (1994) Prolactin sccrction and its control. In: The physiology of reproduction, 2d ed, Vol 1 (Knobil E, Neill JD, eds) pp 1833-1860. New York: Raven.

Ojeda SR, Urbanski HF (1994) Puberty in the rat. In: The physiology of reproduction, 2d ed, Vol 2 (Knobil E, Neill JD, eds), pp 363-409. New York: Raven.

Ojeda SR, Hill DF, Kat $z$ KH (1990) The genes encoding nerve growth factor and its receptor are expressed in the developing female rat hypothalamus. Mol Brain Res 9:47-55.

Reichlin S (1985) Neuroendocrinology. In: Williams textbook of endocrinology (Wilson JD, Foster DW, eds), pp 492-567. Philadelphia: Saunders.

Ricardo JA (1981) Etferent connections of the subthalamic region in the rat. II. The zona incerta. Brain Res 214:43-60.

Rosenthal A, Gueddel DV, Nguyern T, Lewis M, Shih A, Laramee GR, Nikolics K. Winslow JW (1990) Primary structure and biological activity of a novel human neurotrophic factor. Neuron 4:767-773.

Rowland N, Grossman SP, Grossman L (1979) Zona incerta lesions: regulatory drinking deficits to intravenous $\mathrm{CaCl}$, angiotensin, but not to salt in the food. Physiol Behav 23:745-750.

Sanghera MK, Anselmo-Franci J. McCann SM (1991) Effect of medial zona incerta lesions on the ovulatory surge of gonadotrophins and prolactin in the rat. Neuroendocrinology 54:433-438.

Sijverman A-J, Livne I, Witkin JW (1994) The gonadotropin-releasing hormone (GnRH), neuronal systems: immunocytochemistry and in situ hybridization. In: The physiology of reproduction, $2 \mathrm{~d}$ ed, Vol 1 (Knobil E, Neill JD, eds), pp [683-1709. New York: Raven.

Simmons DM, Arriza JL, Swanson LW (1989) A complete protocol for in situ bybridization of messenger RNAs in brain and other tissues with radiolabeled single-stranded RNA probes. J Histotechnol 12: 169-181.

Soppet D, Escandon E, Maragos J, Middlemas DS, Reid SW, Blair J, Burton LE, Stanton BR, Kaplan DR, Hunter T, Nikolics K, Parada LF (199I) The neurotrophic factors brain-derived neurotrophic factor and neurotrophin- 3 are ligands for the $r k B$ tyrosine kinase receptor: Cell 65:895-903.

Springer JE, Robbins E, Meyer S, Baldino F Jr, Lewis ME (1990) Localization of nerve growth factor receptor mRNA in the rat basal forcbrain with in situ bybridization histochemistry. Cell Mol Netrobiol $10.33-39$

Squinto SP, Stitt TN, Aldrich TH, Davis S, Bianco SM, Radziejewski C, Glass DJ, Masiakowski P, Furth ME, Valenzuela DM, DiStefano PS, Yancopoulos GD (1991) $t r k$ B encodes a functional receptor for brain-derived neurotrophic factor and neurotrophin-3 but not nerve growth factor. Cell 65:885-893.

Taniuchi M, Clark HB, Schweitzer JB, Johnson EM Jr (1988) Expression of nerve growth factor receptors by Schwann cells of axotomized peripheral nerves: ultrastructural location, suppression by axonal contact, and binding properties. J Neurosci 8:664-681.

Tsoulfas P, Soppet D, Escandon E. Tessarollo L, Mendoza-Ramirez J, Rosenthal A, Nikolics K. Parada LF (1993) The rat trkC locus encodes multiple neurogenic receptors that exhibit differential response to neurotrophin-3 in PCL2 cells. Neuron 10:975-990.

Valenzuela DM, Maisonpierre PC, Glass DJ, Rojas E, Nuñez L, Kong Y, Gies DR, Stitt TN, Ip NY, Yancopoulos GD (1993) Alternative forms of rat trkC with different functional capabilities. Neuron 10: 963-974.

Wilson CA, James MD, Grierson JP, Hole DR (1991) Involvement of catecholaminergic systems in the zona incerta in the steroidal control of gonadotrophin release and female sexual behaviour. Neuroendocrinology $53: 113-123$.

Yan Q, Johnson EM Jr (1988) An immunohistochemical study of the nerve growth factor receptor in developing rats. J Neurosci 8:34813.

Zhou J, Holtzman DM, Weiner RI, Mobley WC (1994) Expression of TrkA confers neuronlike responsiveness to nerve growth factor on an immortalized hypothalamic cell line. Proc Nat Acad Sci LSA 91: $3824-3828$. 